\title{
Does Cross-Listing Lead to Functional Convergence? Empirical Evidence
}

\author{
Meghana Ayyagari*
}

\begin{abstract}
I examine the effect of legal bonding on ownership and control structures of foreign firms cross-listing in the U.S. Contrary to the predictions of corporate governance convergence theories, there is little evidence of convergence-related migration to a dispersed ownership structure on cross-listing. The paper finds that foreign firms use ADRs as a vehicle to sell control blocks, often to a new foreign owner, rather than as a means to change their governance structure Firms that cross-list and sell stakes to domestic owners are from large economies with high stock market liquidity. In contrast, firm-level characteristics are more important predictors of a control change to a foreign owner. Cross-listing firms that sell control blocks to foreigners tend to be smaller, have low levels of debt and have a high foreign income growth rate. The post cross-listing performance of firms that undergo a control change is also different from firms that do not experience a control change.
\end{abstract}

Keywords: Corporate Governance, Ownership, Legal Environment

JEL Classification: G32 (Financial Policy; Capital and Ownership Structure), K23 (Corporation and Securities Law)

World Bank Policy Research Working Paper 3264, April 2004

The Policy Research Working Paper Series disseminates the findings of work in progress to encourage the exchange of ideas about development issues. An objective of the series is to get the findings out quickly, even if the presentations are less than fully polished. The papers carry the names of the authors and should be cited accordingly. The findings, interpretations, and conclusions expressed in this paper are entirely those of the authors. They do not necessarily represent the view of the World Bank, its Executive Directors, or the countries they represent. Policy Research Working Papers are available online at http://econ.worldbank.org.

*PhD Candidate, Robert H Smith School of Business, University of Maryland, College Park, Maryland 20742.

Email: mayyagar@rhsmith.umd.edu. I am extremely grateful to Vojislav Maksimovic and Gordon Phillips for their guidance and encouragement. I also thank Lemma Senbet, Mark Chen, Thorsten Beck, Inessa Love, Leora Klapper, Peter Murrell and seminar participants at University of Pittsburgh, University of Virginia, University of Colorado, George Washington University, The Brattle Group and the Bank of Canada for helpful comments and suggestions. 


\section{Introduction}

CEOs of foreign companies often cite the desire for increased corporate governance as one of the motivations for cross-listing on US exchanges. ${ }^{1}$ This is supported by the Functional Convergence Hypothesis developed most broadly by Coffee $(1999,2002)$, which states that foreign firms incorporated in a jurisdiction with weak investor protection rights cross-list on US securities markets to "legally bond" themselves to higher disclosure standards and stricter enforcement. This helps them attract investors who would otherwise be reluctant to invest or those who would discount such stocks because of the risk of fraud and embezzlement. However, the empirical evidence on the bonding hypothesis remains mixed. While studies by Reese and Weisbach (2002) and Mitton (2002) provide empirical support for the importance of legal bonding, a more recent study by Seigel (2002) finds that US securities laws were quite ineffective in deterring or punishing insider stealing in a sample of Mexican firms. ${ }^{2}$

In this paper, I provide an alternative approach to test the bonding hypothesis by looking at the effect of legal bonding on ownership and control structures. The seminal work in the area of law and finance by La Porta, Lopez-de-Silanes, Shleifer, and Vishny (henceforth LLSV) (1998) has established that the extent of legal protection provided to minority shareholders in a jurisdiction determines if the firms incorporated in that country have a concentrated or a dispersed ownership structure. A cross-listing by a foreign firm on a US securities market provides a unique opportunity to test what happens to ownership structure when a firm migrates from a poor investor protection environment to one with greater protection for minority investors and better enforcement (the US market).

\footnotetext{
${ }^{1}$ Following is the statement by Mr. H. N. Sinor, the Managing Director \& CEO of ICICI Bank, one of India's largest banks and the first bank from Asia (excluding Japan) to list on the NYSE : “...we wanted to be much more transparent in our disclosures. We adopted US GAAP and the norms specified by the Securities and Exchange Commission (SEC) of the US are much stricter than the norms specified by the Indian regulators - RBI and SEBI. After the ADR issue, we have a class of investors who are more demanding as far as corporate governance and disclosures go. We wanted that we should be constantly evaluated by foreign investors and benchmarked against global companies." http://www.indiainfoline.com/comp/icba/2004.html

${ }^{2}$ Earlier studies such as Fanto (1996) even suggest that SEC requirements for foreign firms are meaningless. Most other authors including MacNeil (2001), Cheung and Lee (1995) and Licht (2001) stress the need for additional empirical work to determine the impact of a US listing on corporate governance.
} 
Recent literature suggests that there are several views on what could happen to ownership structure on cross-listing. One view, supported by theories of functional convergence (Coffee 1999) and by the rent-protection theory of ownership (Bebchuk 1999), predicts that migrating to a corporate law system that effectively limits private benefits of control can produce more efficient choices of ownership structure.

For instance, Coffee (2001) argues that dispersed ownership could arise and persist if there is significant improvement in protection of minority rights in European and transitional economies. Therefore, if cross-listing on the US market accords at least some of this improvement in investor protection for firms listing from these countries, a change in their ownership structures would be expected. John and Kedia (2000) in fact, make the prediction that firms from weak legal regimes should experience rapid changes in corporate governance on cross-listing.

A second view is the path-dependence theory of ownership, proposed by Bebchuk and Roe (1999), which states that the ownership structure of a firm at any point is influenced by the initial ownership pattern due to complementarities, network externalities, and sunk costs. If a firm starts out with a concentrated ownership structure, the controlling owner is likely to retain control or sell the control block to a new incoming shareholder, rather than sell voting rights to a dispersed group of shareholders. Therefore, the theory predicts that the initial ownership patterns of foreign firms persist after cross-listing.

This paper tests the two theories by using a unique database of 425 firms from 42 countries that cross-listed on a major exchange in the United States. I examine time-series changes in ownership and control structures around the date of cross-listing. The aggregate picture shows that a majority of the firms that cross-list have an initial controlling shareholder (73\%) and family ownership is the most dominant form of control-roughly one in two firms has a family as the controlling owner. There also exists a high degree of separation of ownership and control rights in these firms through the use of pyramidal structures and other control-enhancing 
features. And as expected from La Porta, Lopez-de-Silanes, and Shleifer (1999), most of the cross-listing firms that are widely held, to start with, are from English common law countries.

When I examine the change in ownership structure over time, I find that there is a small decline in the percentage of voting rights held by the controlling shareholder in cross-listing firms as compared to a benchmark sample of firms that do not cross-list. This decline is largest for firms from countries with poor investor protection (the French civil law countries) and for firms that start out with initial owners as a state or another corporation. Interestingly, I find that the decline decreases with time. The mean voting rights held by the controlling shareholders decrease in the year of cross-listing and for three years thereafter. However, the controlling shareholders start reconsolidating their position in the fourth and fifth years after cross-listing.

The decline in voting rights around the time of cross-listing is not large enough to result in a widely-held ownership structure, suggesting little evidence of any convergence-related movement. This persistence in concentrated ownership patterns, even after listing on US markets, lends support to the path-dependence theory of ownership structures.

Although most of the companies continue to be controlled by an ultimate owner on cross-listing, I document a high incidence of changes in the identity of the controlling shareholder. Controlling shareholders in $35 \%$ of the sample of cross-listing firms approach US markets as a way to divest their stake and sell their control block. Several reasons contribute to why a US listing might facilitate such a sale, including greater visibility (Baker, Nofsinger, and Weaver (2002)), superior earnings forecasts (Lang, Lins, and Miller (2003), and higher valuations (Doidge et al. (2003)). I elaborate on the reasons in the next section of the paper. Many of the exiting controlling shareholders happen to be either the state or a family and the new entrants are predominantly widely held corporations. Further, I find that more than half of the control changes are to foreign controlling owners.

I then turn to firm and country-level data to get a better understanding of which characteristics influence a change of control in companies on cross-listing. I use the Worldscope 
database as a source of firm-level data for the cross-listing firms. I find that country-level characteristics like size and liquidity of the home country's market and the extent of legal rules and investor protection are significant predictors of a control change to domestic owners. In contrast, individual firm characteristics, such as size, leverage and market valuation are important predictors of control change to foreign owners. Additional tests show that capital control regulations and FDI restrictions in the home country decrease the probability of control changes to foreign shareholders.

Post-listing characteristics of firms that cross-list show that all firms have significantly higher foreign income growth rates. So an ADR listing is able to expand the international orientation of the foreign firms. I also find that firms that undergo control changes, especially to foreign owners significantly increase their leverage ratios.

In summary, the paper shows that the increased regulation associated with US markets is not effective enough in changing the ownership concentration of foreign firms that cross-list on US exchanges. The feature of the US corporate law system that limits private benefits of control doesn't produce an increase in dispersed ownership structures in firms issuing an ADR. However, cross-listing does provide an opportunity for existing shareholders to sell out to new owners as evidenced by the high incidence of control transfers in the study sample. The evidence suggests that rather than bonding there

The paper is organized as follows. Section 2 examines related literature and discusses the main hypothesis this paper tests. Section 3 discusses the data and summary statistics. Section 4 presents the main results. Section 5 concludes with implications for future research.

\section{Motivation and Related Literature}

In this section I identify the different ways in which foreign companies can approach the US markets and the reasons for them to do so. Section 2.1 discusses what an American 
Depositary Receipt (ADR) is and the Securities Exchange Commission (SEC) rules and regulations that a company issuing an ADR is subject to. Section 2.2 discusses the various reasons why a company may cross-list on a US exchange including implications of the bonding hypothesis. Section 2.3 lays out the main hypothesis I test in this paper regarding ownership changes around cross-listing.

\subsection{What are ADRs?}

Firms can migrate to US securities markets either by listing foreign shares through an American Depository Receipt (ADR) on the NYSE, NASDAQ or AMEX or by listing shares directly on these exchanges. An ADR is a negotiable instrument issued by a US commercial bank acting as a depositary and represents a fraction or a multiple of one or more shares of the foreign stock. The shares of foreign stock are on deposit with the depositary's correspondent bank (the custodian bank) located in the home country of the issuer. Firms seeking the benefits of ADRs can choose from four different types of sponsored ADR programs, each with its own set of benefits as well as its own set of legal and regulatory requirements: Level I, Level II, Level III, and Rule 144A/GDR.

A Level I depositary receipt program is the simplest method for companies to access the U.S. and non-U.S. capital markets. Level I depositary receipts are traded in the U.S. OTC market with prices published in the "Pink Sheets" and on some exchanges outside the United States. Establishment of a sponsored Level I program does not require full SEC registration and the companies do not have to report their accounts under U.S. GAAP or provide full SEC disclosure. A company cannot raise capital via a Level I ADR.

Companies that wish to raise capital or make an acquisition using securities, use Sponsored Level II or Sponsored Level III depositary receipts. Level II and Level III depositary receipt programs require SEC registration and adherence to applicable requirements for U.S. GAAP. Reporting requirements include Form F-6 registration statement to register the ADR, 
Form 20-F registration statement that contains detailed financial information about the issuer, and Form F-1 to register the equity securities underlying the ADRs and annual reports.

Foreign companies can also access the U.S. and other capital markets through Rule 144A and/or Regulation S Depositary Receipt facilities without SEC registration. Rule 144A programs provide for raising capital through the private placement of Depositary Receipts with large institutional investors (Qualified Institutional Buyers or QIBs) in the United States. Regulation S programs provide for raising capital through the placement of Depositary Receipts offshore to non-U.S. investors in reliance on Regulation S.

Since I am interested in studying the effect of US laws on ownership changes for crosslisting firms, I use only Level II and Level III ADRs for this study.

\subsection{Why do Firms Cross-List? The Bonding Hypothesis}

There exist several reasons why a company might want to list abroad: to expand investor base, to increase stock liquidity, to improve the terms on which they can raise capital, to increase visibility of the company, and to achieve non-financial benefits such as increasing customer base by broadening product recognition amongst investors of the host country. These and other motivations are reviewed in detail in Karolyi (1998) and Pagano, Roell and Zechner (2002).

This section examines the investor protection and corporate governance argument applied to cross-listing. According to the Bonding Hypothesis, exchanges with strict regulation and disclosure requirements are the ones attracting foreign firms rather than exchanges with inadequate supervision. Below are some of the aspects of greater regulation that cross-listing on a US stock exchange via a Level II or Level III ADR entails:

- Issuer is subject to SEC enforcement

- Issuer is committed to providing full information and to reconciling financial statements to GAAP 
- Issuer is subject to listing requirements imposed by the exchange it lists on

- Issuer is exposed to the "scrutiny of reputational intermediaries including US underwriters, auditors, debt rating agencies and securities analysts" as suggested by Coffee (2002). Lang, Lins and Miller (2002) show that the earnings forecasts of crosslisting firms are superior to those that do not cross-list.

Cantale (1996) and Fuerst (1998) show that firms signal quality by listing on strictly regulated markets. They predict that companies that cross-list on a more demanding exchange should exhibit higher profitability than those that list on exchanges with not so severe regulatory standards. Stulz (1999) predicts that companies from countries with poor legal standards can reduce the agency costs of external finance by subjecting themselves to tighter standards.

However, empirical testing of these models has yielded mixed results. Reese and Weisbach (2002) find that once they control for firm size, firms from weak investor protection countries are less likely to list in the US. However, firms from these countries that do cross-list issue more equity on cross-listing. Another paper that provides a direct test of this hypothesis is by Doidge et. al. (2003), who find that corporate governance seems to be secondary compared to other factors that drive large firms to tap US markets. Seigel (2002) finds that US securities laws are ineffective in punishing expropriation and insider stealing especially if the foreign firm has no assets in the US. So it all comes down to the extraterritorial reach of US securities laws.

The rights accorded to holders of ADRs are determined by a complex interplay of the issuer's home country corporate laws and the US federal securities law. Shareholder rights being the purview of corporate law, the corporate law of the foreign issuer's home country determines the rights and protections for shareholders of the foreign issuer. However, certain corporate governance issues are regulated by US federal securities laws and the rules of the national securities exchanges on which the companies are listed. This is the basis on which the bonding hypothesis presumes that US securities law deters corporate malfeasance by foreign issuers. Further, the recently instituted Sarbanes-Oxley Act of 2002, which is aimed at higher corporate 
accountability to shareholders, extends to all public corporations, including ADR issuers, which have their securities, listed on US exchanges.

However, several factors undermine the importance of US securities law with respect to ADR holders. I discuss some of these below:

- The laws of many countries recognize the depositary bank as the shareholder of the securities underlying the ADR program and not the ADR holders. To be recognized as the shareholder of the underlying securities, many countries require the ADR holders to remove their ADR shares from the program and receive the underlying shares, thereby becoming a registered shareholder of the foreign issuer.

- No NYSE rules regarding notice of shareholder meetings or disclosure of meeting agenda items to holders of ADRs

- Foreign issuers are not subject to the SEC's proxy rules

- Foreign issuers may obtain waivers of holding annual shareholder meetings, including quorum requirements for these meetings

- Depository agreements: In addition to federal securities law, the depository agreements play an important role in determining voting rights of ADR holders. Under some agreements, the issuer agrees to recognize the holders of ADRS as shareholders of the underlying securities and not the depository bank. There is no difference made between holders of ADRs and domestic investors in the foreign country. However some depository agreements severely limit voting rights of the ADR holders. These include prohibiting ADR holders' voting rights other than in limited circumstances; some agreements provide that if ADR holders do not vote, shares are autoproxied to the issuer; many include a disclaimer that there is no guarantee that ADR holders will receive proxy materials in time too exercise their votes and in some agreements, a depository bank that 
is recognized as the shareholder may not split its vote if ADR holders provide conflicting voting.

There also exist several provisions in current SEC regulations to allow for accommodations to foreign issuers. For instance, one of the requirements of Sarbanes Oxley is that listed companies have audit committees consisting of external, independent directors. Some foreign issuers are exempt from this requirement and allowed to have internal auditors, especially when it is authorized by the issuer's home-country statutes. Foreign issuers are also exempt from Regulation Fair Disclosure (Regulation FD) which prohibits the practice of selective disclosure of material nonpublic information by U.S. public companies to securities industry professionals.

In sum, the non-uniformity in regulations that apply to domestic and foreign issuers emphasizes the need for empirical work at the firm level to establish whether legal bonding influences the corporate governance structure of the foreign firms that cross-list on US exchanges. The following section discusses the thought experiment behind this paper.

\subsection{Legal Bonding and Ownership Structure}

This paper tests the effectiveness of increased corporate governance associated with US legal rules on cross-listing firms. LLS (1999) have shown that the level of investor protection in a country is an important determinant of ownership structure of firms. Proponents of the rentprotection theory of ownership like Bebchuk (1999) argue that countries with poor investor protection like French civil law countries have concentrated ownership structures because of the high value of private benefits of control in these countries. In contrast, countries following English common law have more dispersed shareholder structure because the legal rules and enforcement mechanism in these countries limit the existence of control benefits for a large shareholder.

If the bonding hypothesis were to hold, controlling shareholders of cross-listing firms would no longer be able to consume private benefits when subject to stricter US securities laws. 
John and Kedia (2002) in discussing ownership as one of the instruments of corporate governance predict that firms migrating to exchanges with stricter regulation should see a "rapid change in their existing governance structures". Coffee (2001) also predicts a movement towards dispersed ownership structure when there is a reform in the extent of minority shareholder rights protection because of investors' preferences for ownership and liquidity.

The above legal hypothesis of ownership structure is supported by corporate governance convergence theories. According to Coffee (1999) and Gilson (2001), convergence in corporate norms does not always require a formal legislative amendment of corporate laws and codes in different countries. Firms listing on foreign stock exchanges opt into foreign governance standards, thus developing a functional substitute to formal convergence. Therefore cross-listing firms practice legal bonding as a form of functional convergence ${ }^{3}$.

Related to this is the path dependence view of ownership structure, which says that there are significant sources of path dependence in patterns of corporate ownership structure. Initial ownership structures have an effect on subsequent structures because of sunk adaptive costs, network externalities and complementarities. Further, if the initial pattern of ownership structure provides one group of players with relatively more wealth and power, this group would have a better chance to influence the corporate rules, which in turn would reinforce the initial patterns of ownership. So the question comes down to whether the regulations provided by US securities laws for cross-listing firms are strong enough to override the home country's lax regulatory system.

There seem to be other advantages associated with making the transition from a concentrated ownership structure to a dispersed form. For example, Himmelberg, Hubbard and Love (2002) find that ownership concentration increases the cost of capital and leads to

\footnotetext{
${ }^{3}$ Legal theorists distinguish between "formal convergence" and "functional convergence". Formal convergence in corporate governance requires a legislative amendment of corporate codes and Coffee (1999) argues that legislative inertia and role of special interest groups actually hinder formal convergence. Functional convergence, on the other hand, doesn't require formal institutional change and is brought upon by globalization forces which compel firms to revise their governance structure.
} 
inefficiencies in investment. A dispersed ownership structure supported by US laws would help overcome the associated under-investment problem for cross-listing companies.

Cross-listing on a US exchange may also affect ownership structure by facilitating a control transfer. Controlling shareholders who wish to sell their stakes might view issuing an ADR as a way to increase the price at which they can sell their stakes. Several factors could contribute to this: Recent work by Baker, Nofsinger and Weaver (2002) shows that a US crosslisting increases the firm's visibility in the media and among analysts. Lang, Lins and Miller (2002) show that the earnings forecasts of cross-listing firms are superior to those that do not cross-list. This increase in information associated with cross-listing is helpful in making the company attractive to more potential buyers. Further, Diodge et al (2003) have shown that there is a valuation differential associated with cross-listing firms. Finally, just listing on a US exchange could be a signal of quality and adherence to corporate governance for the cross-listing firm. All these reasons contribute to possible changes in ownership and control structure after cross-listing.

This paper is also related to existing literature on ownership changes surrounding the IPO process. Many cross-listing firms are also first-time issuers in that they IPO on US exchanges. Rydqvist and Hogholm (1995) investigate the going public decision in a sample of family-owned corporations in Sweden and find that the original owners liquidate their stakes in a majority of the cases. In a more recent study employing a larger sample, Holmen and Hogfeldt (2002) find that ownership remains controlled subsequent to an IPO offering. While several other studies examine the identity of ownership structures in different countries (including LLS 1999, Claessens et. al. (2000)), this paper is one of the first to study time series changes in ownership structure. 


\section{Sample Construction and Descriptive Statistics}

To study the relationship between cross-listing, corporate governance and ownership structure, I create a sample of foreign firms that listed on a major US stock exchange since the year 1990. The complete list of cross-listing firms is obtained from the Bank of New York's ADR Index. The cross-listing year and type of issue details are also verified using Citibank's ADR Universe. In the event of a discrepancy between the Bank of New York's ADR Index and Citibank's ADR Universe, I use the information that corresponds closest to the list of cross-listing firms obtained from the NYSE and the NASDAQ.

To be included in the final sample, the following criteria are imposed: (1) Since I am interested in testing the effect of US legal rules, I include only Level 2 ADRs and Level 3 ADRs in the sample. Firms that list via Level 1 ADRs (OTC stocks) or Rule 144a are subject to little or no SEC disclosure requirements and do not have to comply with US GAAP and so are excluded from the sample. (2) I use only those cross-listing firms that are covered by Worldscope database. Since most of the firms that cross-list are big companies with high market capitalization, there is little danger of losing out a large sample of the cross-listing firms by using Worldscope. Further, I have access to firm-level data in Worldscope only from the year 1990. So the year 1990 is the initial cut-off date for the sample. (3) Finally, I include only firms for which I can get ownership information from one year prior to cross-listing to one-year after cross-listing. So there is at least three years of ownership information for each cross-listing firm. The final sample extends from 1990 to 2002 and contains 425 firms that cross-listed on a major US stock exchange.

\subsection{Cross-listing by Year, Exchange and Country}

Panel A of Table I shows the distribution of the sample by year of listing and exchange. More number of firms list on the NYSE, which has the strictest disclosure requirements than on the NASDAQ. Very few firms list on AMEX stock exchange. 
Panel B of Table I presents data on cross-listing by country of origin. Following LLSV (1998), the countries are further classified on the basis of their legal tradition into English Common Law, French civil law, German civil law, Scandinavian civil law and Socialist Law countries. I exclude cross-listing firms from China since it does not belong to any of the legal traditions identified above. I also exclude cross-listing firms from Canada since none of them issue ADRs and all are direct cross-listings. The sample confirms the findings of Reese and Weisbach (2002) that more firms list from French civil law countries than from English common law countries and they do so disproportionately on the NYSE than on the NASDAQ. While $81 \%$ of firms from French civil law countries list on the NYSE, only 53\% from the English common law countries do so.

\subsection{Ownership Characteristics-Prior to Cross-listing}

For each of the companies in the sample, I identify who the ultimate owner of the company is, what his cash flow to voting rights are and whether there has been a change in ultimate owner from two years prior to issuing an ADR to five years, post-listing.

As a starting point for the data collection, I use Worldscope, which provides annual data on the names and holdings of all owners that hold more than $5 \%$ of a company's stock. This information is supplemented with data from a variety of sources to include all owners who have more than $5 \%$ of outstanding stock and are missing in Worldscope. All the sources used are listed country-wise in Appendix B.

For the years prior to ADR listing, the main sources of data are Worldscope and company annual reports filed either with the domestic stock exchange or published on the company web pages. Other data sources include country specific company handbooks like the Brazil Company Handbook and Venezuelan Company Handbook and international databases such as Mergent International.

The ownership information for the years after ADR listing is more easily available because a large fraction of the ADRs file Form 20-F with the SEC. Section 7 of this form titled 
Major Shareholders and Related Party Transactions (prior to 1999, it was Section 4 titled Control of Registrant) requires the ADR issuer to list all persons known to the company to own directly or indirectly more than $5 \%$ of the issued classes of stock. Further, the company is required to mention if there have been any significant changes in ownership structure in the past three years. Consequently, many companies provide detailed time-series information on major shareholdings in their 20-F statements. The source for the 20-F filings was both Lexis-Nexis and Hoovers Online. In all cases, the ownership information is collected for the end of the fiscal year or the closest possible date. This is because ownership information typically lags by about six months in the 20-F filings and by one or two years in the Company Handbooks and Worldscope.

I include companies for which it is possible to determine that all the major shareholders are listed or if it is possible to identify the shareholder who owns $50 \%$ or more of the cash flow rights. For cases in which the shareholder owns less than $50 \%$ and the rest is held by nominee accounts, I use the 20-F statements to decide whether or not to include the company in the sample ${ }^{4}$

The ADR firms are divided into firms that are widely held and those with controlling ultimate owners. The procedure for identifying the ultimate owners is similar to the one in LLS (1999) and Claessens et. al. (2000). I use two cut-off levels, $20 \%$ and $10 \%$ to identify ultimate owners. An ultimate owner is therefore defined as someone who has $20 \%$ (or $10 \%$ ) or more of the control votes of the company and is not controlled by anyone else. This sometimes involves tracking down ownership along multiple chains to find the major shareholders in the major shareholders and so on till we arrive at an ultimate owner who is not controlled by anyone else. The identity of the ultimate owners is further classified into five types: widely held corporation, widely held financial institution, families (or individuals with large stake), state (or government or kingdom) and miscellaneous. The miscellaneous category typically includes cooperatives,

\footnotetext{
${ }^{4}$ This is different from Claessens et al (2000) who actually drop such companies. My justification for including it is that I use $20-\mathrm{F}$ statements to verify whether the nominee accounts are widely held or in the hands of a controlling shareholder.
} 
voting trusts (as is common in Netherlands) or a business group with no single controlling investor. If a firm does not have an ultimate owner, it is classified as widely held. If a firm has multiple ultimate owners, I pick the largest ultimate owner for the analysis.

Panel A of Table II presents ownership statistics at the $20 \%$ cut-off level and Panel B presents statistics at the $10 \%$ cut-off level. The firms are classified by the legal system they belong to and by the identity of the controlling shareholder. The two panels show similar trends at the two cut-off levels. The largest fraction of cross-listing firms that are widely held are from English common law countries (61\% and $49 \%$ at the $20 \%$ level and $10 \%$ levels respectively). This is to be expected since LLS (1999) have shown that dispersed ownership is a characteristic of only English common law countries.

Further, family ownership seems to be the most predominant form of control across all other legal traditions. For the whole sample, out of 425 cross-listing firms, at the $10 \%$ cut-off level, 310 firms have a controlling owner of which 151 firms are controlled by a family. The smallest group of ultimate owners is widely held corporations (21 out of 310 ). The state controlled firms are typically ones that used American Depositary Receipts as a privatization vehicle.

\subsection{Degree of Separation of Ownership and Control-Prior to cross-listing}

For each firm in the sample, I make the distinction between ownership (cash flow rights) and control (voting rights) using the procedures in Claessens et al (2000) and LLSV (1999). As an example, consider the simplest case in which Firm A owns $25 \%$ of Firm B which in turn owns $60 \%$ of Firm C. Assuming that A is a widely held corporation, $\mathrm{C}$ is classified as being controlled by a widely held corporation, which is A, who owns $15 \%$ of the cash flow rights (product of the ownership stakes along the chain) and $25 \%$ of the voting rights (weakest control chain) of C. In many cases, the ultimate owner (here A) could have several control right chains through which he controls C. Then the ultimate control share is given by the sum of the weakest control shares along each chain. For instance if A also held $50 \%$ of Firm D which held $35 \%$ of $\mathrm{C}$, then ultimate 
control share of $\mathrm{A}$ via $\mathrm{B}$ and $\mathrm{D}$ would be $=25+35=60 \%$ while the total cash flow rights of $\mathrm{A}$ would be $=0.25 * 60+0.50 * 35=32.5 \%$.

Panel A of Table III presents the cash flow and voting rights of the controlling shareholders for the full sample and also on the basis of the identity of controlling shareholder and legal tradition. The data are presented for the year of cross-listing. Full sample characteristics show that the percentage of voting rights held by the controlling shareholder are significantly different from the cash flow rights at the $1 \%$ level. This separation of ownership and control is further reflected for each type of controlling owner. The separation is maximum in the case of family controlled enterprises (-5.12\% at $1 \%$ significance) and least for firms controlled by a widely held corporation. (-1.48\%). The degree of separation is also seen by looking at the ratio of cash flow rights to voting rights $(\mathrm{C} / \mathrm{V})$. The mean $\mathrm{C} / \mathrm{V}$ for the whole sample is 0.89 , which implies that the mean controlling shareholder can control $100 \%$ of the voting rights using only $89 \%$ of the cash flow rights. The same statistics are reported for different legal traditions. Separation is least significant for firms listing from English common law countries (-1.8\%) and maximum for firms from French civil law countries (-6.8\%). There does not appear to be much separation of cash flow and voting rights in the firms listing from German and Scandinavian civil law countries or from Socialist law countries.

The ratios are also significantly different from each other across different legal traditions as shown in Panel B of Table III. Panel B of Table III also reports the mean ratio of cash flow to voting rights when countries are classified on the basis of Law and Enforcement, Financial Development and Transparency. To investigate if the degree of law and enforcement in the home country of the cross-listing firm affects the ratio of cash flow to voting rights, I use three alternate measures from LLSV (1998): Shareholder Rights, Law and Order Score and Judicial Efficiency. The countries are classified into high and low depending on the median value of each of these measures. 
Shareholder Rights is a measure of shareholder rights protection in the country. It is an index of "anti-director" rights ranging from 0 to 6 from LLSV (1998) which is formed by aggregating six important shareholder rights. Law and Order Score is a measure of the law and order tradition in the country ranging from 1 to 10 from the International Country Risk Guide. Judicial Efficiency is another index scored 0 to 10 from the country-risk rating agency Business International Corporation that is an assessment of the efficiency of the legal environment from the investors' perspective.

On all three measures, I find that firms need a larger portion of cash flow rights to control $100 \%$ of the firm in countries with good legal rules and enforcement. In comparison, the ratios are significantly lower for cross-listing firms from countries that are not protective of investors.

In addition to shareholder protection variables, I investigate if the ratio of cash flow to voting rights in cross-listing firms also varies with the level of financial development of their home country. Lins, Strickland and Zenner (2003) and Reese and Weisbach (2002) show that firms from emerging markets are more likely to cross-list. I use three different but comparable measures from the Financial Structure Database constructed by Beck et. al (2000) : Higher values of The Index of Financial Structure indicate a more market based financial system. Developed is a dummy that takes the value 1 if the firm's home market is developed and 0 if it is an emerging market firm. Overall Size is a variable indicating the overall size of the financial system (both the stock market and the banking sector). See Appendix A for a detailed description of the variables definition and their sources.

I find that ratio of cash flow to voting rights is significantly lower for emerging economies and for firms coming from countries with small financial systems. Firms from countries with more market based economies have higher cash flow to voting rights indicating that financial structure of the home market is a significant determinant of the extent of control benefits in firms. 
Finally since all firms that cross-list via a Level II or Level III ADR have to conform to US GAAP, I investigate if the cash flow to voting rights ratio varies with home country's accounting standards. I use an Accounting index produced by the Center for International Financial Analysis and Research Inc that is a measure of disclosure requirements and transparency in accounting statements produced by firms in different countries. Poorer the accounting standards, one would expect controlling shareholders to be better able to divert funds and expropriate requiring a lower amount of cash flow to voting rights. I find that the ratio is 0.86 for firms with poor accounting standards, which is significantly lower than the ratio of 0.95 for firms with good accounting standards.

\subsection{Use of Control Enhancing Features --Prior to cross-listing}

The ways in which cash flow rights can be different from control rights is through the use of dual classes of stock, pyramidal structures and cross shareholdings. I create dummies for each of these categories. Dual-Class equals one if the firm issues multiple classes of shares with different voting rights, Pyramid equals one if the controlling owner exercises control through at least one publicly traded company and Cross-Shareholding equals 1 if the company has a controlling shareholder and owns a percentage of shares in either its controlling shareholder or in any other company in that chain of control. I also define dummies to identify if there is just one controlling owner, Single, and if any person from higher management is also from the controlling family, Management. See Claessens et al (2000) for detailed description of these variables.

Table IV presents details on the prevalence of various control enhancing features in different cross-listing firms. As in Table III, firms are classified on the basis of their home country's legal rules, law and enforcement, financial development and accounting standards. The use of multiple classes of shares with different voting rights is significantly higher (lower) in firms from French civil law (English common law) countries than in firms cross-listing from other countries. The use of pyramidal structures seems to be quite high (around 50\%) in most of 
the companies irrespective of the legal system they belong to. Cross-shareholding structures are more common in Scandinavian countries in this sample.

When countries are classified on the basis of shareholder rights protection and legal enforcement, I find that pyramiding is very common in firms whose home countries are not very protective of minority shareholders (61\%), have low law and order scores $(57 \%)$ and rank low on the score of judicial efficiency (53\%). Similar statistics hold for the use of multiple voting classes of shares. $37 \%$ of firms listing from countries with poor legal and judicial systems use multiple classes of shares as compared to only $10 \%$ of firms coming from protective legal and efficient judicial systems. Therefore, I find that the use of control enhancing structures in firms that crosslist from different countries is very representative of the overall use of these structures in those economies as discussed in LLS (1999).

I also find that firms from developed countries and firms from countries with large financial systems and market based economies are less likely to have multiple classes of voting shares and less likely to have a single controlling shareholder. This is as expected because a growing body of research has shown that a country's set of legal rules and legal institutions is important for explaining the level of bank and stock market development (LLSV 1998). Hence one would expect ownership concentration levels and general ownership characteristics to vary with the level of financial development of the home market.

In addition, the controlling shareholder belongs to upper management in most of the firms listing from under-developed economies. On the account of level of transparency in the accounting system of the country, I find that firms that cross-list from countries with poor accounting standards have significantly higher pyramidal structures, multiple classes of shares and single controlling shareholders. 


\section{Empirical results}

\subsection{Changes in Voting Rights}

In this section, I document the change in voting rights of cross-listing firms after they cross-list on a major exchange in the US via a Level II or Level III ADR program. I first examine these changes by classifying firms by their home country's legal tradition. Table III shows that there is a significant difference in cash flow and voting rights, prior to cross-listing, between firms belonging to different legal traditions and levels of shareholder protection. It is therefore worthwhile to examine if the changes in the legal and regulatory environment that cross-listing firms are subject to, upon issuing an ADR, translate into changes in ownership concentration as predicted by the rent protection theory of ownership. Finally, I also assess if the changes in voting rights are different for different groups of shareholders. The purpose is to examine if a US listing affects certain groups of controlling shareholders more than other groups.

Panel A and B of Table V report the percentage changes in voting rights at the two cutoff levels of $20 \%$ and $10 \%$ ownership concentration during a six-year period $(-1,+5)$ around the cross-listing year. The statistics reported are group means for different groups of home countries of the cross-listing firm classified on the basis of legal origin. I also report statistics for a comparison sample of benchmark firms from each country that do not cross-list.

A perfect control sample would be the Level I ADRs that trade on OTC markets because while these firms cross-list, they are not subject to SEC enforcement or exchange listing rules. However, the lack of SEC filings of these companies makes it extremely difficult to find their ownership information. To construct the comparison sample, for each cross-listing firm, I find a firm matched by industry (four-digit SIC) and nearest asset size from Worldscope. If there is no match at the four-digit SIC level, I look at three or two-digit SIC codes before applying the size criterion. The final restriction for the non cross-listing firm to be included in the sample is the availability of good ownership information from Mergent International and country specific 
sources. In about $20 \%$ of the cases, the availability of ownership information over-rides the size criterion. Further, to minimize the data collection without losing out on the representative-ness of the comparison sample, I adopt the following sampling method: If a country has five or less than five firms issuing ADRs, I try to identify a match for each of the five firms. However, if the country has more than 5 firms cross-listing in the US, then I randomly sample 5 of them and identify comparison firms for each of those. I track ownership details for the comparison firms for only two years, the year prior to cross-listing (of the firm that it is a match to) and four-five years after cross-listing.

One of the sample selection issues here is that the cross-listing firms are very different from the home country firms that do not cross-list. To address this issue, I compare the ownership characteristics of the domestic firms to the cross-listing firms prior to their listing in the US. I find that both samples have high concentration of ownership structures and family ownership is predominant in both the domestic non-crosslisting firms and the cross-listing sample. In addition, the mean separation of cash flow and voting rights is similar in both samples. For instance, family owned firms that cross-listed in the US had a mean ratio of 0.85 in the year prior to cross-listing compared to a mean ratio of 0.83 for family owned firms in the control sample. Cross-listing firms from French civil law countries had a ratio of 0.86 compared to 0.84 for control sample firms from these countries. Test of means reveals all statistics to be significant at the $1 \%$ level. These tests show that the ownership profile and the potential for private benefits of control is similar in the domestic control sample firms and the firms that cross-listed, suggesting that the control sample constructed here is a good match for the main sample.

A comparison of the ownership structures of the control and the treatment sample exhibit significant similarities. Both samples have concentrated ownership structures, predominantly family ownership and similar separation of cash flow and voting rights. The ratio of cash flow to voting rights is 0.86 for the cross-listing firms from French civil law countries and is 0.84 for the 
firms that do not cross-list from these countries. The breakdown of statistics by type of owner is not reported for brevity and is available from the author.

Both panels $\mathrm{A}$ and $\mathrm{B}$ of Table $\mathrm{V}$ report negative but insignificant decreases in the year prior to cross-listing $(-2,-1)$. There are highly significant but small decreases in voting rights in the year of the cross-listing and thereafter. The largest decrease in voting rights in both panels occurs during the $(-1,+3)$ period and this is slightly reduced during the $(-1,+5)$ period. For example at the $10 \%$ level, voting rights decrease by $6.03 \%$ during the period $(-1,+3)$ and only by $5.46 \%$ during the period $(-1,+5)$. Similar results are obtained when the sample size is kept fixed over all periods (results not reported). In contrast, for the comparison sample, the results show a slight but insignificant decrease of $-2.96 \%(-3.45 \%)$ at the $20 \%(10 \%)$ ownership concentration level.

The results suggest that issuance of an ADR is accompanied by a decrease in control rights held by the concentrated shareholder when compared to firms from the same country that do not issue an ADR. However, the decrease is definitely not of a large enough magnitude to result in a change to a widely held ownership structure. In fact, in the fifth year after cross-listing there is actually a slight increase in percentage of control rights.

Table V also reveals that the firms from French civil law countries experienced the largest decrease in voting rights $(-9.38 \%$ at $20 \%$ level and $-9.31 \%$ at $10 \%$ level) over the period $(-1,+3)$. These changes are significantly different from zero at the $1 \%$ level. In comparison, corresponding numbers for firms from English common law countries were $-2.52 \%$ and $-3.39 \%$ respectively. The latter firms also registered a slight increase in voting rights over the period (-1, $+5)$. Ownership changes seem to be the least in Scandinavian and Transition economies.

In Table VI, I examine the change in voting rights for different types of controlling shareholders. The table reports changes in voting rights for the original controlling shareholder over different periods of time surrounding the year of cross-listing. If the original controlling 
shareholder loses control during the period of study, then he is no longer included in the observations.

Table VI reveals some important differences between family and state controlled firms. I find that family controlled firms experience only a small decline of $5.8 \%$ over the period $(-1,+3)$, which reduces to $3.9 \%$ over the period $(-1,+5)$. This suggests that family controlled firms reduce their control rights up to year three after cross-listing but actually start increasing control thereafter. This could reflect one of two things: The controlling shareholders reduce their stake at the time of cross-listing to signal their interest in corporate governance and attract more investors but tend to reconsolidate soon after. Alternatively, it could also mean that they take advantage of the valuation premium associated with cross-listing (Doidge et. al (2003)) and sell a part of their stake only to buy back after year three when valuations have returned to normal.

State controlled firms, on the other hand, experience significant and large declines of $17.2 \%$ and $22 \%$ over the periods $(-1,+3)$ and $(-1,+5)$ respectively. So unlike the family controlled firms' state controlled firms continue to divest their stake in year four and five. The large decline in voting rights experienced by state controlled enterprises is not very surprising because a lot of privatizations of state-owned assets have been carried out by issuing American depositary receipts. This is especially true for countries in Latin America. The best example is that of the Brazilian telecommunication giant Telebras, a $\$ 37$ billion company. When the Brazilian government decided to privatize Telebras in 1998 and break it up into 12 smaller units, 12 separate ADR issues were established on the New York Stock Exchange. One of the reasons why governments decide to use global equity markets for privatization, apart from wanting to increase investor base is that in many countries, the home market is unable to absorb such a large tranche. Hence they are compelled to look at international markets to raise capital. On going privatizations could also explain the finding that unlike family controlled firms, state controlled firms continue to divest their stake in year four and five. 
Table VI also shows that companies controlled by corporations and widely held financial institutions exhibit a similar pattern as family controlled firms. Firms controlled by corporations and financial institutions experience large declines in control over the period $(-1,+3)$ of $26.7 \%$ and $14.5 \%$ respectively which reduces when over a longer period of $(-1,+5)$. This seems to suggest that cross-listing firms controlled by corporations and financial institutions also do a lot of selling and buy-back around the cross-listing date to take advantage of valuation premiums. The larger decline in the case of corporations and financial institutions could reflect the lower use of multiple classes of shares in these types of firms. Family owned firms, on the other hand, would prefer to use shares with low or no voting rights to take advantage of the valuation premium since they value control more. Hence the study shows only a small decline in voting right shares in the case of family owned firms.

While the decline in voting rights is not significant to result in a widely-held ownership structure, there exist other changes in ownership structures as described in the section below.

\subsection{Changes in Control of Cross-listing Firms}

In this section, I examine the incidence of control changes taking places in the sample of firms that cross list on a major exchange in the United States. A change in control is registered when the original shareholder completely divests his stake to a new party or if the original controlling shareholder sells a sufficient portion of his stake such that he no longer has the maximum percentage of voting rights. A change in control is also registered if a widely held firm sees the emergence of a controlling shareholder within five years after cross-listing.

Appendix D shows an example of control change associated with an ADR listing in the case of Vimpel-Communications (VimpelCom), which in 1996 became the first Russian company to trade on the New York Stock Exchange. The controlling shareholder of the company in the year prior to ADR issuance (1995) was the founder of the company, Dr Dmitri Zimin, who was also president and CEO. Dr Zimin owned $45 \%$ of the cash flow rights of VimpelCom and 
controlled $58.6 \%$ of the company's voting stock. By 2001, VimpelCom had two new majority shareholders: Alfa group who controlled 25\% plus two shares of VimpelCom's voting stock via the company EcoTelecom Ltd. and Telenor, Norway's leading telecommunications company which controlled $25 \%$ plus 13 shares of VimpelCom's voting stock.

The full sample characteristics show that roughly $35 \%$ of the firms that had an original controlling shareholder experience a change in control within five years of cross-listing in the US. Panel A of Table VII provides a detailed breakdown of control changes by type of controlling shareholder. The first column of Table VII provides the number of control changes taking place for each type of original controlling shareholder and the last row of Table 8 shows the emergence of new controlling shareholders. Out of the 78 control changes in the study, most occurred in cases where the original controlling shareholder was a family (26 out of 78) or the state (22 out of 78). The 26 families that exited, transferred control to 7 new families, 8 public corporations, one state, 4 widely held financial institutions and 3 changes were classified as miscellaneous. Three of the 26 families completely divested their stake resulting in a widely held corporation. Overall, 11 of the 78 control changes resulted in the original firm becoming widely held.

Table VII also shows that the largest number of new controlling shareholders are widely held corporations and widely held financial institutions. Only 16 of the 78 control changes resulted in a new family being in control compared to 38 changes to a widely held corporation or financial institution.

Panel B provides a better sense of net changes in controlling shareholder types. The table shows the change in controlling shareholder type from prior cross-listing to post cross-listing for the sample of firms that underwent control changes. There is a total decrease of $11.7 \%$ and $24.2 \%$ in the presence of family controlled and state controlled firms respectively, over the period (-1, +5 ) indicating that these types of controlling shareholders are most likely to sell their stakes on cross-listing. On the other side, the controlling shareholder that emerges most after a control change is a widely held corporation or a widely held financial institution. This implies there is a 
degree of movement away from state and family ownership in some companies cross-listing in the US.

An interesting result from panel $\mathrm{B}$ is that $45.3 \%$ of control changes result in a foreigner being in control. This seems to indicate that a US cross-listing provides a way for the domestic controlling shareholder to divest his stake to a foreign owner. Empirical studies have shown that cross-listing on a highly liquid market like the US increases visibility (Merton's (1987) investor recognition hypothesis) and also sends out a good signal that the firm believes in good corporate governance because it is bonding to greater transparency (Coffee (1999) and Stulz (1999)). These two features would make it easier for a controlling shareholder to sell his control block to a foreign owner.

Table VIII presents a first comparison of the companies that cross-list with those that do not cross-list. The cross-listing sample is split up into firms that undergo a control change and those that do not. The table computes the difference in median values for some important balance sheet variables such as leverage, total assets, return on assets, total asset growth and foreign income growth. The differences are computed by estimating a median quantile regression (LAV) on a constant, a time dummy variable which captures time relative to the year of cross-listing as well as control dummies for calendar year and country. I investigate three relative time periods: PRELISTING (year before cross-listing), CLYEAR (year of cross-listing) and POSTLISTING (five years after cross-listing).

The table reveals some interesting patterns for the firms that undergo a control change and those that don't. All cross-listing firms seem to be significantly larger than companies that do not cross-list. This finding is consistent with Pagano, Roell and Zechner (2002) who argue that there exist economies of scale in cross-listing which increases with company size. The company growth variables show that there cross-listing is associated with high growth rates for the firms. Total asset growth peaks in the year before (or in the year of) cross-listing for both samples of companies that undergo a control change and those that do not. The foreign income growth 
variable is also significantly larger for all cross-listing companies compared to the control group. There is also some evidence linking international presence to a control change because the foreign growth rates for the firms that undergo a control change are larger than the growth rates for companies that do not undergo a control change.

The table also shows the difference in leverage ratios for the two samples relative to the control sample. A significant finding of the table is that the leverage ratios of the firms that undergo a control change are significantly higher in the year of the cross-listing and five years later. This seems to suggest that some of the firms cross-list to increase their debt capacity and this effect of increase in debt capacity is experienced mainly by firms that undergo a change in their control structure.

Tobin's Q ratios are significantly higher for all cross-listing firms in the year prior to crosslisting but this difference remains only for firms that do not undergo a control change. In fact, firms that undergo a control change in this sample are found to have a decreased Tobin's Q ratio in the year of the cross-listing. Finally, the return on asset measure is significantly higher for all cross-listing firms only in the year of cross-listing. This is suggestive of window dressing by the ADR issuing firms

\subsection{Predicting Control Change from Company Characteristics}

The descriptive statistics discussed in the last two sections provide some evidence that there is a change in the identity of the controlling shareholder in firms that cross-list in the US. In this section I turn to more rigorous regression analysis to investigate the control changes in detail. I use duration analysis to determine which company characteristics predict a control change and multinomial logit analysis to predict when control change results in a foreign shareholder. I also use multinomial logit analysis on a smaller sub sample of OECD countries to study the effect of restrictions on foreign direct investment on control change. 
In Table IX, the determinants of a control change occurring within five years of crosslisting are analyzed using a Cox proportional hazard rate model. This methodology is useful in predicting discrete events (recorded as failures) in a panel setting and has been used by Pagano et. al (2002) in examining the decision by firms to cross-list. It estimates the effects of a set of covariates $\mathrm{X}$ influencing the probability of undergoing a control change at time $\mathrm{t}$ (the probability is referred to as the hazard rate $\mathrm{h}(\mathrm{t}))$. The model is written as:

$$
h(t)=h_{o}(t) \exp \left(X^{\prime} \beta\right)
$$

where $\beta$ is a vector of coefficients and $h_{0}(t)$ is the baseline hazard rate (that is the hazard rate when all $\mathrm{X}$ variables are set to 0 ). The Cox proportional hazard rate estimator is a semi parametric estimator and is referred to as proportional hazard because it assumes that the hazard ratio $h(t) / h_{o}(t)$ is constant for any two firms at any point in time.

Table IX reports the estimates as exponentiated coefficients $\left(\exp \left(\beta_{1}\right), \exp \left(\beta_{2}\right), \ldots\right)$ rather as coefficients $\left(\beta_{1}, \beta_{2}, \ldots\right)$, because exponentiated coefficients can be readily interpreted as the effect of unit change in independent variable $X$ on the hazard ratio $h(t) / h_{o}(t)$.

The set of determinants include both firm-level characteristics and characteristics of the home country of the cross-listing firm. The set of firm characteristics include age of the firm, size (measured as logarithm of total assets), leverage ratio, Tobin's Q, total asset growth and total foreign income growth of the company. I also use lagged values of the following country-level variables: GDPCAP is the log of GDP per capita of the home economy, TVT_GDP is stock market total value-traded to GDP which is defined as total shares traded on domestic stock market exchange to GDP, COMMON is a legal origin dummy which takes the value 1 for English common law countries and 0 otherwise, PROPERTY is the property rights regulation index from LLSV (1999) and the Index of Economic Freedom, and is a measure of the degree to which the government protects private property, and CAPCONTROL is an index of capital control regulations, as in Harrison et. al. (2003), constructed from the International Monetary 
Fund's annual report, Trade and Exchange Restrictions. This is a composite index constructed by taking into account five types of control restrictions on international transactions. Thus, this measure is reflective of the openness of a country's economy. The standard errors and p-values are adjusted for clustering on companies to allow for dependence of errors concerning the same company.

Table IX shows that the variables that have the greatest impact on a control change occurring are size of the company and leverage. A unit increase in leverage decreases the relative hazard of a control change by $83.2 \%$ and a unit increase in size increases the probability of a control change by $19.5 \%$ respectively. This suggests that larger companies and companies with less debt are more likely to undergo a control change. This could be because investors are reluctant to buy control blocks in highly levered companies and it is the larger companies who are able to cross list outside the home market and take advantage of increased visibility to facilitate a control change.

An increase in Tobin's Q ratio decreases the probability of a control change by just $1.4 \%$ (significant at 0.001 level). This seems surprising at first because one would expect investors wanting to buy control blocks in companies with high market valuation. But a high market valuation also implies that the concentrated shareholder is more reluctant to sell his control block and hence there are a lesser number of control changes in these companies. I also find that foreign income growth enters significantly into the regression. An increase in foreign income growth results in an increase in the probability of a control change by $6.7 \%$. This table however doesn't reveal if the foreign income growth predicts a control change to domestic or to foreign shareholders. This issue is addressed in Table X.

Among the country-level characteristics, I find that the economic size and liquidity of the home country's economy have a large positive and significant effect. This suggests that it is easier to sell control blocks if the home country's economy is big and the stock exchange is very liquid. Further, control change is less likely in English common law countries, which is to be 
expected because most of the cross-listing firms from these nations do not have a concentrated shareholder and Table VII reveals very few changes from a widely held ownership structure to concentrated ownership on cross-listing. The extent to which a government protects private property and enforces laws to protect private property also seems to be determining factor of control changes. Cross-listing firms are less likely to sell their control blocks to a new controlling owner on cross-listing if their home market is protective of property rights. So control changes following ADR issuance are more common in countries that have poor property rights protection. I also find the interesting result that a unit increase in capital control restrictions decreases the probability of a control change by almost $8.8 \%$. Therefore probability of a control change on issuing an ADR is decreased if the home country's economy is not very open and is subject to severe capital control restrictions. Firms from such economies are not very attractive to investors even after they issue an ADR.

\subsection{Emergence of a new foreign controlling shareholder}

This section investigates if control changes result in a foreign controlling shareholder. Multinomial logit is used to predict whether a company is more likely to experience a control change resulting in a new domestic owner, or in a foreign owner, or becomes widely held or does

not experience a control change at all. The regressors are lagged as before and standard errors are adjusted to allow for clustering.

Table $\mathrm{X}$ reports the relative risk ratios when control change results in a new domestic owner, a new foreign owner, or in the firm becoming widely held. The base line case is when there is no control change. The set of independent variables used are the same firm and countrylevel characteristics used in Table IX with one change. I substitute capital control regulations with the level of foreign direct investment, FDI, taken from the IMF's Balance of Payment Statistics and YEARS_LIBER which is the number of years since the official date of 
liberalization of the country (from Bekaert and Harvey 2000). FDI is a measure of foreign direct investment in the recipient country scaled by aggregate gross domestic investment.

There exist interesting dis-similarities between the three groups. Country characteristics like GDP per capita and TVT_GDP are significant predictors of control change to a new domestic controlling owner. Odds that a controlling shareholder sells his stake to another domestic shareholder rather than retaining his stake is 1.14 times higher if his company is located in a developed economy and is 13.68 times higher if the stock exchange of the home country has high liquidity. So greater the financial development of the home country's economy and greater the liquidity of the home country's stock exchange, more companies sell their stakes to a domestic controlling owner on cross-listing. On the other hand, odds that the controlling shareholder sells his stake to a foreign owner decrease by $98 \%$ with each 1 -unit increase in the liquidity of the home market's stock exchange. This suggests that the size and liquidity of the home country's stock exchange is a significant determinant of whether control is transferred to a domestic owner or a foreign owner.

Table $\mathrm{X}$ also reveals that increased property rights regulation increases the odds of a dispersed ownership structure after cross-listing and decreases the odds of a control change to a domestic controlling owner. It has a positive but insignificant effect on odds of a foreign controlling owner emerging post cross-listing. This suggests that use of an ADR to sell a control block to another shareholder is rare in countries that are protective of property rights. This is broadly consistent with recent evidence on privatizations. Megginson, Nash, Netter and Poulsen (2001) find that the sale of control blocks is easier where governments respect property rights. Hence firms in these countries do not need to approach global markets to sell their control blocks.

The level of foreign direct investment into the home country also has a significant effect on the sale of a control block to a foreign owner. This seems to suggest that a foreign sale is easier when the home country is already open to foreign investors. I don't find any of the country 
level characteristics to be significant predictors of the emergence of dispersed ownership structures on cross-listing.

Firm-level characteristics, on the other hand, serve as important predictors for control change to a widely held ownership structure. Odds of a controlling shareholder completely divesting his stake, resulting in a widely held company, are higher for companies with higher market valuations. Further, age comes in as a significant predictor only for companies moving from a concentrated ownership to a dispersed ownership structure (ages decreases the odds by 71\%). Further, larger the company, less likely it is to move to a dispersed ownership structure.

Table $\mathrm{X}$ also shows the firm level characteristics that predict control change to a foreign owner. Size and leverage of the cross-listing are highly significant indicators of a control change to a foreign owner. The odds are decreased by $37 \%$ and $70 \%$ for large firms and highly levered firms respectively. This seems to suggest that only small companies and companies with low debt are attractive to foreign investors. This both supports and contrasts a recent study by Freund and Djankov (2000) who find that foreign investment in Korea is focused on larger firms and firms with low debt ratios. However, the authors in that study focus on direct foreign investment and not on firms issuing ADRs. In addition, I find that the odds of a new foreign controlling owner are 1.15 times higher (increases about 151\%) among firms with high foreign income growth. The number of years since official liberalization of the country does not enter significantly into any of the regressions. In summary, Table $\mathrm{X}$ reveals that individual firm characteristics are important if a firm wishes to use the ADR route to divest to a new foreign owner.

One of the main policies that governments use to discriminate between foreign and domestic investors is the use of foreign direct investment (FDI) restrictions. Hence, a good measure to determine the emergence of a foreign controlling shareholder would be to use a measure of restrictions on foreign direct investment and foreign ownership of equity in different countries. However, data on this is available only for a small sample of OECD countries. Golub (2003) presents a score of overall restrictiveness indicators, RESTRICTION, for OECD countries 
based on regulations in three areas: restrictions on foreign ownership, screening and approval procedures used by countries to limit FDI and other restrictions (that include constraints on the ability of foreign nationals to manage or work in foreign companies, operational requirements, stipulations on nationals forming a majority of the board of directors and so on). The score ranges from 0 to 1 with 1 being the case when no foreign equity is allowed.

Table XI uses the RESTRICTION measure in a multinomial logit regression to study its effect on emergence of a foreign controlling shareholder. I find that greater the level of FDI restrictions in the country, probability of a control change to a foreign owner on issuing an ADR drops by $94 \%$.

In summary, sale of control blocks on cross-listing, to shareholders in the same country, is largely dictated by the home-country's stock market development and legal environment. However, sale of control blocks to a foreign owner seems to be more influenced by firm-level characteristics than country-level characteristics of the home country. The tables show that an ADR issuance helps small, young firms with low debt and a high foreign income growth rate leapfrog the drawbacks of their home-country environment and complete a successful block sale on the global market.

\subsection{Ex-Post Characteristics}

In this section, I examine the effects of cross-listing and control change on the subsequent performance of companies. Each variable to be estimated $\mathrm{y}_{\mathrm{it}}$ (eg: the leverage ratio of a company $i$ at time $\mathrm{t}$ ) is regressed on a set of cross-listing dummies as shown below:

$y_{i t}=\alpha_{0}+\alpha_{1} f_{i}+\beta_{1}$ CLYEAR $_{i t}+\beta_{2} Y E A R 3_{i t}+\beta_{3} Y E A R 5_{i t}+\varepsilon_{i t}$

where $f_{i}$ denotes a company fixed effect, CLYEAR $\mathrm{it}_{\mathrm{it}}$ is a dummy intended to capture the impact of cross-listing of company I, YEAR $3_{\text {it }}$ is a dummy corresponding to the three years after listing, and YEAR $_{\text {it }}$ is a dummy capturing the permanent shift in the dependent variable after cross- 
listing (takes the value 1 after year3 of cross-listing). To eliminate fixed effects, I difference both sides of the equation and estimate Least Absolute-Value (LAV) regressions to distinguish between the various impacts. The specification on first-differencing is now:

$$
\Delta y_{i t}=\beta_{1} \Delta C L Y E A R_{i t}+\beta_{2} \Delta Y E A R 3_{i t}+\beta_{3} \Delta Y E A R 5_{i t}+\Delta \varepsilon_{i t}
$$

Table XII reports the LAV-regression results for cross-listing firms that do not undergo a control change (Panel A) and for firms that do undergo a control change (Panel B). The two panels reveal that all firms irrespective of control change experience a big increase in total asset growth in the year of the cross-listing. The similarities however end here. Total asset growth is seen to reduce in companies that do not undergo a control change but increases in companies that do. The companies that undergo a control change experience a $23.6 \%$ reduction in total assets accompanied by a very high increase in leverage ratios. Companies that do not report a control change, on the other hand, experience a $1.4 \%$ increase in total assets and a $2 \%$ decrease in leverage, both of which are not significant.

Both samples of cross-listing firms show a peak in total asset growth in the year of crosslisting but this growth rate is not sustained in the long run. Foreign income growth, on the other hand, is significantly higher for the long-term. This is consistent with evidence from Pagano et al (2003) that cross-listing is pursued by more export oriented firms and firms wishing to expand in international markets.

There is also a significant difference in leverage ratios of firms that cross-list and undergo control changes and those that don't. Table XII reveals that firms that undergo control changes raise significant amounts of debt in the years after cross-listing. Two factors could be responsible for this result. The high leverage ratios could be associated with foreign firms which issued an ADR as part of privatization. Recent privatization literature (Frydman et al 2000) has shown that massive restructuring is associated with firms that privatized and sold stakes to foreign owners and raising debt could be part of this restructuring process. Another factor that could contribute to 
this is the identity of the new owners. The transition matrix in Table VII shows that control changes resulted in more financial institutions and corporations being in control than a state or a family. So it could be that foreign equity investors such as banks also lend to the firm thereby driving the result that firms with control changes raise more debt on cross-listing. This is consistent with evidence presented in a recent paper by Aggarwal and Klapper (2003) where they report a similar symbiotic relationship between foreign ownership and lending in a sample of Indian IPOs.

Further, companies that undergo a control change also show an increase in ROA and a decrease in Tobin's Q ratio, which is not exhibited by firms that do not undergo a control change. Overall, companies that undergo a control change after cross-listing seem to become more exportoriented and increase their debt capacity substantially. While the accounting profitability measures shows an increase in profitability in these companies, the market valuation of the company is seen to reduce. One possible explanation for this could be that if the original controlling shareholder is better informed of the future value of the company and he uses the amount of equity retained as a signal of company's value, the divestment on the part of the owner is interpreted as a negative signal by the market Leland and Pyle (1977).

\section{Conclusions}

This paper examines if cross-listing on a US exchange results in a change of ownership and control structure for foreign firms. The paper tackles this issue in two parts. First it examines if there is a movement from concentrated ownership structures to dispersed ownership structures as

predicted by recent literature in law and finance. The bonding hypothesis by Coffee (1999) predicts that foreign firms cross-list on US exchanges to bond themselves to higher disclosure standards and stricter enforcement. This implies that cross-listing should be associated with some change in governance structure for the foreign firms. The paper shows that there is no such mass 
transformation of ownership structures. Most of the firms that cross-list have concentrated shareholdings and continue to do so after cross-listing. This finding questions the hypothesis that legal protections provided by cross-listing are effective enough to cause firms to change their governance structure.

Second the paper examines if there any changes in composition of the shareholders on crosslisting. The paper finds that an ADR listing facilitates a control transfer in a large fraction of firms and $45 \%$ of these transfers results in a foreign controlling owner on cross-listing. The finding suggests that the ADR is used as a vehicle by the controlling shareholder to sell his control block. A listing on a US exchange provides him with increased visibility and an increased investor base required for selling the control block, both in the home country and to a foreign owner.

The post listing characteristics of the cross-listing firms reveals that the firms that undergo a control change have a large foreign income growth and significantly increase their debt capacities post cross-listing. While their return on assets shows a permanent positive increase, these firms have a slightly negative Tobin's Q ratio in the long run. On the other hand, companies that do not undergo a control change do not increase their leverage ratios and have high Tobin's Q ratios in all years after cross-listing.

A possible explanation for the absence of a change in ownership concentration is the presence of complementarities between a firm's selection of governance structure and the prevailing institutional environment. As long as foreign issuers are still held more accountable to home country laws and are subject to different governance standards than domestic US firms, the institutional environment that these firms operate in on cross-listing is not very different and hence there is unlikely to be a transformation in their governance structures. I turn to a theoretical exploration of these issues in Ayyagari (2003). 


\section{References}

Aggarwal, R. and Klapper,L. (2003) : Ownership Structure and Initial Public Offerings. Unpublished working paper. World Bank

Ayyagari, M. (2003) : Effect of Investor Protection and Strategic Complementarities on Organizational Design. Unpublished working paper.

Baker, K., Nofsinger, J., and Weaver, D. (2002) : International cross-listing and visibility. Journal of Financial and Quantitative Analysis 37(3), 495-521.

Bebchuk, L. A. (1999) : A Rent Protection Theory of Corporate Ownership and Control. NBER Working Paper No. 7203

Bebchuk, L. A. and Roe, M. (1999) : A Theory of Path Dependence in Corporate Ownership and Governance, Stanford Law Review 52. 775-808.

Beck, T., Demirguc-Kunt, A., and Levine, R. (2000) : A New Database on Financial Development and Structure. World bank Economic Review. 597-605.

Bekaert, G. and Harvey, C.R. (2000) : Foreign Speculators and emerging equity markets. Journal of Finance 55, 565-614.

Cheung, C. S. and Jason, L. (1995) : Disclosure Environment and Listing on Foreign Stock Exchanges. Journal of Banking and Finance 19(2), 347-62.

Claessens, S., Djankov, S. and Lang, L. (2000) : The separation of ownership and control in East Asian corporations. Journal of Financial Economics 58, 81-112.

Coffee, J. C. (1999) : The Future as History: The prospects for global convergence in corporate governance and its implications. Northwestern University Law Review 93, 641-708.

Coffee, J. C. (2002) : Racing Towards the Top? The Impact of Cross-listings and Stock Market Competition on International Corporate Governance. Columbia Law Review 102(7).

Coffee, J. C. (2001) : The Rise of Dispersed Ownership: The Role of Law in the Separation of Ownership and Control. Yale Law Journal 111, 1-82

Doidge, C., Karolyi, A. and Stulz, R. (2003) : Why are Foreign Firms Listed in the U.S. Worth More? Journal of Financial Economics forthcoming.

Fanto, J.A. (1996) : The Absence of Cross-Cultural Communication: SEC Mandatory Disclosure and Foreign Corporate Governance. Journal of International Law and Business 17, 119-207.

Foerster, S.R. and Karolyi, A. (1993) : International Listings of Stocks: The Case of Canada and the US. Journal of International Business Studies 24: 763-784.

Foerster, S.R. and Karolyi, A. (1998) : Multimarket Trading and Liquidity: A Transactions Data Analysis of Canada-US Interlistings. Journal of International Financial Markets 8, 393-412. 
Foerster, S.R. and Karolyi, A. (1999) : The Effects of Market Segmentation and Investor Recognition on Asset Prices: Evidence from Foreign Stocks Listing in the United States, Journal of Finance 54, 981-1013.

Freund, C. and Djankov, S. (2000) : Which Firms do Foreigners Buy? Evidence from Korea. World Bank Working Paper \#2450.

Frydman, R., Hessel, M.P., and Rapaczynski, A. (2000) : Why Ownership Matters? Entrepreneurship and the Restructuring of Enterprises in Central Europe. New York University Department of Economics Working Paper.

Fuerst, O. (1998) : A Theoretical Analysis of the Investor Protection Regulations Argument for Global Listing of Stocks. Unpublished manuscript.Yale School of Management.

Gilson, R. (2001) : Globalizing Corporate Governance: Convergence of Form or Function. 39 American Journal of Comparative Law 329.

Golub, S. (2003) : Measures of restrictions on inward foreign direct investment for OECD countries. OECD Economics Department Working Paper \#357.

Harrison, A., McMillan, M.S., and Love, I. (2004) : Global Capital Flows and Financing Constraints. Journal of Development Economics forthcoming.

Himmelberg, C., Hubbard, G., and Love, I. (2002) : Investor protection, Ownership and Investment. World Bank Working Paper \#2834.

Holmen, M. and Hogfeldt, P. (2002) : A Law and Finance Analysis of Initial Public Offerings. SSRN Working Paper Series.

John, K. and Kedia, S. (2000) : Design of Corporate Governance: Role of Ownership Structure, Takeovers, Bank Debt and Large Shareholder Monitoring. Harvard working paper.

Karolyi, A. (1998) : Why do companies list shares abroad? A survey of the evidence and its managerial implications, Financial Markets, Institutions and Instruments Vol. 7 Blackwell Publishers, Boston.

La Porta, R., Lopez-de-Silanes, F., Shleifer, A., and Vishny R. (1998) : Law and Finance. Journal of Political Economy 106, 1113-1155.

La Porta, R., Lopez-de-Silanes, F., Shleifer, A., and Vishny R. (1999) : The quality of Government. Journal of Law, Economics and Organization 15, 222-279.

La Porta, R., Lopez-de-Silanes, F., Shleifer, A., and Vishny R. (1999) : Corporate ownership around the world. Journal of Finance 54, 471-517.

Lang, M., Lins, K., and Miller, D. (2003) : ADRs, Analysts and Accuracy: Does Cross-listing in the US Improve a Firm's Information Environment and Increase Market Value? Journal of Accounting Research 41(2)

Leland, H.E. and Pyle, D.H. (1977) : Informational Asymmetries, Financial Structure, and Financial Intermediation. Journal of Finance 32, 371-387. 
Licht, A.N. (2000) : Genie in a Bottle: Assessing managerial opportunism in international securities transactions. Columbia Business Law Review 51 (1).

Licht, A.N. (2001) : Managerial Opportunism and Foreign Listing: Some Direct Evidence. University of Pennsylvania Journal of International Economic Law 22, 325-348.

Lins, K., Strickland, D., and Zenner, M. (2003) : Do non-US firms issue equity on US stock exchanges to relax capital constraints. Journal of Financial and Quantitative Analysis forthcoming.

MacNeil, I. (2001) : Competition and Convergence in Corporate Regulation: The Case of Overseas Listed Companies. University of Aberdeen working paper.

Megginson, W.L., Nash, R.C., Netter, J.N., and Poulsen, A.B. (2001) : The Choice of Private versus Public Capital Markets: Evidence from Privatizations. SSRN Working Paper Series.

Merton, R.(1987) : Presidential address: A simple model of capital market equilibrium with incomplete information. Journal of Finance 47, 2035-2054.

Miller, D.(1999) : The Market Reaction to International Cross-listings: Evidence from Depository Receipts. Journal of Financial Economics 103.

Mitton, T. (2002) : A cross-firm analysis of the impact of corporate governance on the East Asian financial crisis. Journal of Financial Economics 64(2).

Pagano, M. and Roell, A.A. (1998) : The Choice of Stock Ownership Structure: Agency Costs, Monitoring and the Decision to go Public. Quarterly Journal of Economics 113, 187-225.

Pagano, M., Roell, A.A., and Josef, Z.(2002) : The Geography of Equity Listing: Why do Companies List Abroad? Journal of Finance forthcoming.

Reese, W. and Weisbach, M. (2002) : Protection of Minority Shareholder Interests, CrossListings in the United States, and Subsequent Equity Offerings. Journal of Financial Economics $66,65-104$.

Rydqvist, K. and Hogholm, K. (1995) : Going Public in the 1980s: Evidence from Sweden. European Financial Management 1(3), 287-315.

Siegel, J. (2002) : Can Foreign Firms Bond Themselves Effectively by Renting US Securities Laws? MIT Working Paper

Stulz, R. M. (1999) : Globalization of Equity Markets and the Cost of Capital. Journal of Applied Corporate Finance, 8-25. 


\section{Table I}

\section{Descriptive Statistics}

The table presents summary statistics on the number of cross-listings in the United States by year and by country of incorporation. The sample consists of foreign firms that listed their shares on one of the major US exchanges (Amex, NASDAQ or NYSE) via Level II or Level III ADR Programs. Only exchange listed ADRs are considered because they require specific accounting and disclosure information for a firm to cross-list. Panel A shows cross-listing statistics by year. Panel B shows the number of firms that were crosslisted from each country. The countries are also divided into five categories depending on the legal regime they belong to-English Common Law, French Civil Law, German Civil Law, Scandinavian Civil Law and Socialist Law

Panel A: Cross-Listing Statistics by Year

\begin{tabular}{ccccc}
\hline & & Cross-Listings & & \\
\cline { 2 - 5 } Year & AMEX & NASDAQ & NYSE & Total \\
\hline 1990 & 0 & 2 & 10 & 5 \\
1991 & 0 & 1 & 5 & 11 \\
1992 & 0 & 5 & 19 & 10 \\
1993 & 1 & 3 & 25 & 23 \\
1994 & 1 & 6 & 15 & 32 \\
1995 & 0 & 6 & 25 & 21 \\
1996 & 0 & 16 & 36 & 41 \\
1997 & 0 & 18 & 37 & 54 \\
1998 & 0 & 11 & 23 & 48 \\
1999 & 1 & 21 & 48 & 45 \\
2000 & 0 & 30 & 29 & 78 \\
2001 & 0 & 9 & 14 & 38 \\
2002 & 1 & 4 & 289 & 19 \\
Total & 4 & 132 & 425 \\
\hline
\end{tabular}

Panel B: Cross-Listing by Country

\begin{tabular}{clcccc}
\hline & \multicolumn{4}{c}{ Cross-Listings } \\
\cline { 2 - 6 } Legal Origin & Nation & AMEX & NASDAQ & NYSE & Total \\
\hline English Common Australia & 0 & 7 & 6 & 13
\end{tabular}




\begin{tabular}{|c|c|c|c|c|c|}
\hline \multirow[b]{2}{*}{ Legal Origin } & \multirow[b]{2}{*}{ Nation } & \multicolumn{4}{|c|}{ Cross-Listings } \\
\hline & & AMEX & NASDAQ & NYSE & Total \\
\hline \multirow[t]{10}{*}{ Law } & $\overline{\text { Ghana }}$ & 0 & 0 & 1 & 1 \\
\hline & Hong Kong, China & 0 & 5 & 3 & 8 \\
\hline & India & 0 & 3 & 8 & 11 \\
\hline & Ireland & 0 & 8 & 5 & 13 \\
\hline & Israel & 0 & 5 & 3 & 8 \\
\hline & New Zealand & 0 & 1 & 4 & 5 \\
\hline & Singapore & 0 & 2 & 0 & 2 \\
\hline & South Africa & 0 & 5 & 4 & 9 \\
\hline & United Kingdom & 3 & 30 & 41 & 74 \\
\hline & Total & 3 & 66 & 75 & 144 \\
\hline \multirow[t]{19}{*}{ French Civil Law } & Argentina & 0 & 3 & 9 & 12 \\
\hline & Belgium & 0 & 0 & 1 & 1 \\
\hline & Brazil & 0 & 1 & 29 & 30 \\
\hline & Chile & 0 & 0 & 20 & 20 \\
\hline & Colombia & 0 & 0 & 1 & 1 \\
\hline & Dominican Republic & 0 & 0 & 1 & 1 \\
\hline & France & 0 & 12 & 21 & 33 \\
\hline & Greece & 0 & 2 & 3 & 5 \\
\hline & Indonesia & 0 & 0 & 2 & 2 \\
\hline & Italy & 0 & 1 & 10 & 11 \\
\hline & Luxembourg & 0 & 4 & 2 & 6 \\
\hline & Mexico & 1 & 1 & 24 & 26 \\
\hline & Netherlands & 0 & 7 & 18 & 25 \\
\hline & Peru & 0 & 0 & 2 & 2 \\
\hline & Philippines & 0 & 1 & 1 & 2 \\
\hline & Portugal & 0 & 0 & 3 & 3 \\
\hline & Spain & 0 & 1 & 5 & 6 \\
\hline & Turkey & 0 & 0 & 1 & 1 \\
\hline & Venezuela & 0 & 0 & 2 & 2 \\
\hline
\end{tabular}




\begin{tabular}{|c|c|c|c|c|c|}
\hline \multirow{3}{*}{ Legal Origin } & \multirow[b]{2}{*}{ Nation } & \multicolumn{4}{|c|}{ Cross-Listings } \\
\hline & & AMEX & NASDAQ & NYSE & Total \\
\hline & Total & 1 & 33 & 155 & 189 \\
\hline \multirow{7}{*}{$\begin{array}{l}\text { German } \\
\text { Civil Law }\end{array}$} & Austria & 0 & 0 & 1 & 1 \\
\hline & Germany & 0 & 7 & 14 & 21 \\
\hline & Japan & 0 & 10 & 11 & 21 \\
\hline & Korea, Rep. & 0 & 3 & 5 & 8 \\
\hline & Switzerland & 0 & 2 & 10 & 12 \\
\hline & Taiwan & 0 & 2 & 3 & 5 \\
\hline & Total & 0 & 24 & 44 & 68 \\
\hline \multirow{5}{*}{ Scandinavian Law } & Denmark & 0 & 1 & 1 & 2 \\
\hline & Finland & 0 & 0 & 4 & 4 \\
\hline & Norway & 0 & 1 & 3 & 4 \\
\hline & Sweden & 0 & 6 & 1 & 7 \\
\hline & Total & 0 & 8 & 9 & 17 \\
\hline \multirow{4}{*}{ Socialist Law } & Hungary & 0 & 0 & 1 & 1 \\
\hline & Poland & 0 & 1 & 0 & 1 \\
\hline & Russian Federation & 0 & 0 & 5 & 5 \\
\hline & Total & 0 & 1 & 6 & 7 \\
\hline
\end{tabular}


Table II

Ownership Characteristics of the Cross-Listing Firms

The table classifies foreign firms that listed their shares on one of the major US exchanges (Amex, NASDAQ or NYSE) on the basis of their country of incorporation and their ownership structures. The countries are divided into five categories depending on the legal regime they belong to-English Common Law, French Civil Law, German Civil Law, Scandinavian Civil Law and Socialist Law. The ownership details are reported for the year the firm cross-lists in the US. A firm is classified as widely held if it does not have a controlling shareholder in that year. A firm is classified as having a controlling shareholder if it has an ultimate owner who controls at least $20 \%$ (10\%) of the firm's votes. Panel A B) presents statistics for the $20 \%(10 \%)$ cutoff level. The identity of the controlling shareholder is presented using the classification scheme in La Porta et. al (1999). Panel A also reports the mean age of the firms that cross-list. Detailed variable definitions and the sources of ownership data are presented in the Appendix.

Panel A: At the 20\% cut-off level

\begin{tabular}{|c|c|c|c|c|c|c|c|c|c|}
\hline \multirow{2}{*}{ Legal Origin } & \multirow{2}{*}{$\begin{array}{l}\text { Number of } \\
\text { countries }\end{array}$} & \multirow{2}{*}{$\begin{array}{l}\text { Number of } \\
\text { firms }\end{array}$} & \multirow{2}{*}{ Age } & \multirow{2}{*}{$\begin{array}{c}\text { Widely } \\
\text { Held }\end{array}$} & \multicolumn{5}{|c|}{ Identity of Controlling Shareholder } \\
\hline & & & & & Family & State & $\begin{array}{l}\text { Widely held } \\
\text { corporation }\end{array}$ & $\begin{array}{l}\text { Widely held } \\
\text { financial }\end{array}$ & Miscellaneous \\
\hline English Common Law & 10 & 144 & 22 & 88 & 32 & 9 & 3 & 8 & 4 \\
\hline French Civil Law & 19 & 189 & 31 & 35 & 77 & 29 & 16 & 4 & 28 \\
\hline German Civil Law & 6 & 68 & 28 & 36 & 10 & 8 & 4 & 1 & 9 \\
\hline Scandinavian Law & 4 & 17 & 11 & 7 & 5 & 4 & 1 & 0 & 0 \\
\hline Socialist Law & 3 & 7 & 24 & 1 & 2 & 4 & 0 & 0 & 0 \\
\hline Full Sample & 42 & 425 & & 167 & 126 & 54 & 24 & 13 & 41 \\
\hline
\end{tabular}

Panel B: At the 10\% cut-off level

\begin{tabular}{|c|c|c|c|c|c|c|c|c|c|}
\hline \multirow{3}{*}{ Legal Origin } & \multirow{3}{*}{$\begin{array}{l}\text { Number of } \\
\text { countries }\end{array}$} & \multirow{3}{*}{$\begin{array}{c}\text { Number of } \\
\text { firms }\end{array}$} & \multirow{3}{*}{ Age } & \multirow{3}{*}{$\begin{array}{c}\text { Widely } \\
\text { Held }\end{array}$} & \multicolumn{5}{|c|}{ Identity of Controlling Shareholder } \\
\hline & & & & & & & & & \\
\hline & & & & & Family & State & $\begin{array}{l}\text { Widely held } \\
\text { corporation }\end{array}$ & $\begin{array}{l}\text { Widely held } \\
\text { financial }\end{array}$ & Miscellaneous \\
\hline English Common Law & 10 & 144 & 22 & 71 & 45 & 8 & 7 & 10 & 5 \\
\hline French Civil Law & 19 & 189 & 31 & 18 & 79 & 36 & 6 & 16 & 33 \\
\hline German Civil Law & 6 & 68 & 28 & 22 & 17 & 8 & 7 & 1 & 11 \\
\hline Scandinavian Law & 4 & 17 & 11 & 3 & 7 & 5 & 1 & 1 & 0 \\
\hline Socialist Law & 3 & 7 & 24 & 0 & 3 & 4 & 0 & 0 & 0 \\
\hline Full Sample & 42 & 425 & & 115 & 151 & 61 & 21 & 28 & 49 \\
\hline
\end{tabular}




\section{Table III}

\section{Cash Flow and Voting Rights of Controlling Shareholders}

The table presents the mean cash flow rights, voting rights and ratio of cash flow to voting rights of all firms that had a controlling shareholder in the year in which they crosslisted on a major exchange in the United States. A firm is classified as having a controlling shareholder if it has an ultimate owner who controls at least $20 \%$ of the firm's votes. Panel A presents statistics for firms classified on the basis of (1) Identity of controlling shareholder: The ultimate owner could be a family (or individual), the state, a widely held corporation, a widely held financial institution or could be miscellaneous, which includes business groups, voting trusts, foundations et. Al) (2) Legal origin: The firms are classified according to the legal system they belong to into English common law, French civil law, Scandinavian civil law, German civil law and Socialist law. The last column presents the difference of means test between cash flow rights and voting rights.

Panel B presents the mean ratio of cash flow to voting rights for countries classified into several categories: (1) Legal Origin: Countries are classified on the basis of English Common Law (dummy=1), French civil law (dummy=1) and German and Scandinavian Civil Law (dummy=1) (2) Law and Enforcement : Countries are sub-classified on the basis of (a) High vs. Low Shareholder Rights-The Anti-director rights index (scored 1-6) is an index aggregating shareholder rights and is used to distinguish between countries that are protective of shareholders and those that are not. (b) High vs. Low Law \& Order Score-Law and Order is an index scored 1-10 where higher score implies strong law and order tradition and lower score implies weak law and order tradition. The countries are classified into high and low based on median values of the Law and Order Scores for the countries in the sample (d) High vs. Low Judicial Efficiency-A high score implies a country with a well functional judicial system and a low score implies a poor judicial system.

(3) Financial Development: Countries are sub-classified on the basis of (a) Index of Financial Structure-Higher Values of this Index imply a more market based financial system.

(b) Large vs. Small Financial System-Overall size of the financial system is measured as deposit money bank assets and stock market capitalization as a share of GDP. The countries are classified into high and low based on median values of the overall size variable for the countries in the sample. (c) Developed vs. Under-developed-Develop is a dummy variable which takes the value zero if both priv (claims on private sector by deposit money banks as a share of GDP) and tvt (Total Value traded on the stock market as a share of GDP) are below the period mean, 1 otherwise. (3) Transparency: Countries are classified on the basis of the Accounting Standards Index, scored from 0 to 90, where a higher score indicates greater disclosure requirement in the countries.

\section{Panel A: Cash Flow and Voting Rights}

\begin{tabular}{|c|c|c|c|c|c|}
\hline & Category & Cash Flow Rights (\%) & Voting Rights (\%) & Ratio & Test of Means \\
\hline & Full Sample & 44.76 & 50.23 & 0.89 & $-6.82^{* * *}$ \\
\hline \multirow{5}{*}{$\begin{array}{l}\text { Identity of } \\
\text { controlling } \\
\text { shareholder }\end{array}$} & Family & 45.67 & 49.79 & 0.85 & $-5.12^{* * *}$ \\
\hline & State & 54.64 & 57.37 & 0.94 & $-2.68^{* * *}$ \\
\hline & Corporation & 47.13 & 50.38 & 0.94 & $-1.80^{*}$ \\
\hline & Financial & 21.96 & 28.97 & 0.83 & -1.48 \\
\hline & Miscellaneous & 40.21 & 45.87 & 0.88 & $-3.23^{* * *}$ \\
\hline \multirow{4}{*}{ Legal Origin } & English Common Law & 34.86 & 35.78 & 0.97 & $-1.87^{*}$ \\
\hline & French Civil Law & 49.55 & 57.47 & 0.86 & $-6.76^{* * *}$ \\
\hline & German Civil Law & 42.21 & 42.26 & 1.00 & -0.05 \\
\hline & Scandinavian Civil Law & 42.26 & 55.36 & 0.70 & $-2.09^{*}$ \\
\hline
\end{tabular}


Panel B: Ratio of Cash Flow to Voting Rights

\section{Legal Origin}

\begin{tabular}{lccc}
\hline & Dummy=0 & Dummy=1 & Test of Means \\
\hline English Law & 0.87 & 0.97 & $-2.39^{* *}$ \\
French Civil Law & 0.95 & 0.86 & $2.95^{* * *}$ \\
Scandinavian Civil Law & 0.91 & 0.70 & $2.55^{* *}$ \\
\hline & & & \\
Law and Enforcement & & & Test of Means \\
\hline Shareholder Rights & Low & High & $-2.82^{* * *}$ \\
Law \& Order & 0.86 & 0.95 & $-2.80^{* * *}$ \\
Judicial Efficiency & 0.85 & 0.94 & $-3.07^{* * *}$ \\
\hline
\end{tabular}

\section{Financial Development}

\begin{tabular}{lccc}
\hline & Low & High & Test of Means \\
\hline Index of Financial Structure & 0.86 & 0.96 & $-3.39^{* * *}$ \\
Overall Size & 0.83 & 0.95 & $-3.61^{* * *}$ \\
Develop & 0.80 & 0.95 & $-4.77^{* * *}$ \\
\hline
\end{tabular}

\section{Transparency}

\begin{tabular}{lccc}
\hline & Low & High & Test of Means \\
\hline Accounting & 0.86 & 0.94 & $-2.41^{* *}$ \\
\hline$* * *$ and $* * *$ & represent significance at $10 \%, 5 \%$ and $1 \%$ level respectively &
\end{tabular}




\section{Table IV}

\section{Control Enhancing Features of Cross-Listing Firms}

The table classifies countries into two groups in each of four categories: (1) Legal Origin: On the basis of legal origin, countries are further classified into (a) English Common Law countries or others (b) French civil countries or others and (c) Scandinavian civil law countries or others. (2) Law and Enforcement: Countries are sub-classified into (a) High vs Low Shareholder Rights-The Anti-director rights index (scored 1-6) is an index aggregating shareholder rights and is used to distinguish between countries that are protective of shareholders and those that are not. (b) High vs. Low Minority Rights-Minority Rights is a dummy variable which takes the value 1 if the Company Law or Commercial Code of the country grants minority shareholders a judicial venue to challenge management decisions, 0 otherwise. (c) High vs. Low Law \& Order Score-Law and Order is an index scored 1-10 where higher score implies strong law and order tradition and lower score implies weak law and order tradition. The countries are classified into high and low based on median values of the Law and Order Scores for the countries in the sample (d) High vs. Low Judicial Efficiency-A high score implies a country with a well functional judicial system and a low score implies a poor judicial system. (3) Financial Development: Countries are sub-classified on the basis of (a) Market vs. Non-market based-Market is a dummy which equals one if country has a market based financial system, 0 otherwise. (b) Large vs. Small Financial System-Overall size of the financial system is measured as deposit money bank assets and stock market capitalization as a share of GDP. The countries are classified into high and low based on median values of the overall size variable for the countries in the sample. (c) Developed vs. Under-developed-Develop is a dummy variable which takes the value zero if both priv (claims on private sector by deposit money banks as a share of GDP) and tvt (Total Value traded on the stock market as a share of GDP) are below the period mean, 1 otherwise. (4) Transparency: Countries are classified on the basis of the Accounting Standards Index, scored from 0 to 90, where a higher score indicates greater disclosure requirement in the countries. In all cases, $\mathrm{N}$ represents the number of firms with controlling shareholders in the category, Cross-Shareholding represents the percentage of firms which have cross-holdings (if the company owns any amount of shares in its controlling shareholder or in another company in its chain of control), Pyramids represents the percentage of firms which have pyramidal ownership structures (where controlling owner exercises control through at least one publicly traded company), Single represents the percentage of firms which have only one controlling shareholder, Management represents the percentage of firms which have the CEO, board chairman, or vice-chairman from the controlling family and Multiple Shares represents the percentage of firms which have multiple classes of shares with different voting rights.

\begin{tabular}{|c|c|c|c|c|c|c|c|}
\hline Category & & $\mathbf{N}$ & $\begin{array}{l}\text { Cross } \\
\text { Shareholding }\end{array}$ & Pyramid & Single & Management & $\begin{array}{l}\text { Multiple } \\
\text { classes }\end{array}$ \\
\hline \multirow{9}{*}{ Legal Origin } & English Common Law & 57 & 0.04 & 0.47 & 0.21 & 0.42 & 0.05 \\
\hline & Others & 205 & 0.07 & 0.50 & 0.42 & 0.30 & 0.29 \\
\hline & Test of Means & & -0.96 & -0.43 & $-3.05^{* * *}$ & 1.57 & $-3.87^{* * *}$ \\
\hline & French Civil Law & 157 & 0.06 & 0.52 & 0.44 & 0.32 & 0.34 \\
\hline & Others & 105 & 0.07 & 0.47 & 0.28 & 0.34 & 0.09 \\
\hline & Test of Means & & -0.31 & 0.71 & $2.72^{* * *}$ & -0.41 & $4.91^{* * *}$ \\
\hline & Scandinavian Law & 10 & 0.30 & 0.40 & 0.20 & 0.40 & 0.40 \\
\hline & Others & 252 & 0.05 & 0.50 & 0.38 & 0.33 & 0.23 \\
\hline & Test of Means & & $3.22^{* * * *}$ & -0.69 & -1.20 & 0.44 & 1.19 \\
\hline
\end{tabular}




\begin{tabular}{|c|c|c|c|c|c|c|c|}
\hline Category & & $\mathbf{N}$ & $\begin{array}{l}\text { Cross } \\
\text { Shareholding }\end{array}$ & Pyramid & Single & Management & $\begin{array}{l}\text { Multiple } \\
\text { classes }\end{array}$ \\
\hline \multirow{9}{*}{ Law and Enforcement } & Low Shareholder Rights & 152 & 0.07 & 0.61 & 0.43 & 0.32 & 0.30 \\
\hline & High Shareholder Rights & 110 & 0.04 & 0.41 & 0.29 & 0.34 & 0.15 \\
\hline & Test of Means & & 0.38 & $3.26^{* * *}$ & $2.41^{* *}$ & -0.23 & $3.01^{* * *}$ \\
\hline & Low Law \& Order Score & 134 & 0.04 & 0.57 & 0.37 & 0.33 & 0.37 \\
\hline & High Law \& Order Score & 128 & 0.08 & 0.42 & 0.38 & 0.33 & 0.10 \\
\hline & Test of Means & & -1.14 & $2.25^{* *}$ & -0.08 & -0.04 & $5.25^{* * *}$ \\
\hline & Low Judicial Efficiency & 129 & 0.05 & 0.53 & 0.46 & 0.30 & 0.37 \\
\hline & High Judicial Efficiency & 133 & 0.07 & 0.47 & 0.29 & 0.35 & 0.11 \\
\hline & Test of Means & & -0.47 & 0.88 & $2.74^{* * *}$ & -0.92 & $5.31^{* * *}$ \\
\hline \multirow{9}{*}{ Financial Development } & Small Financial System & 112 & 0.05 & 0.50 & 0.49 & 0.38 & 0.40 \\
\hline & Large Financial System & 145 & 0.07 & 0.49 & 0.29 & 0.29 & 0.11 \\
\hline & Test of Means & & -0.50 & 0.22 & $3.23^{* * *}$ & 1.20 & $5.58^{* * *}$ \\
\hline & Under-developed & 97 & 0.07 & 0.59 & 0.46 & 0.41 & 0.46 \\
\hline & Developed & 158 & 0.06 & 0.43 & 0.33 & 0.28 & 0.09 \\
\hline & Test of Means & & 0.42 & $2.17^{* *}$ & $1.97^{* *}$ & $2.04^{* *}$ & $7.23^{* * *}$ \\
\hline & Non-Market Based & 105 & 0.04 & 0.41 & 0.37 & 0.28 & 0.17 \\
\hline & Market based & 157 & 0.08 & 0.55 & 0.38 & 0.36 & 0.28 \\
\hline & Test of Means & & -1.24 & $-2.26^{* *}$ & -0.03 & -1.39 & $-1.98^{* *}$ \\
\hline \multirow{3}{*}{ Transparency } & Low Accounting Standards & 131 & 0.05 & 0.55 & 0.46 & 0.32 & 0.36 \\
\hline & High Accounting Standards & 131 & 0.07 & 0.44 & 0.29 & 0.34 & 0.11 \\
\hline & Test of Means & & -0.46 & $1.88^{*}$ & $3.01^{* * *}$ & -0.13 & $4.98^{* * * *}$ \\
\hline
\end{tabular}


Table V

\section{Changes in Voting Rights Surrounding Cross-Listing-Comparison by Country}

The table shows the changes in voting rights of the largest controlling shareholder for the sample of foreign firms that cross-listed on one of the major US exchanges during the years 1990 to 2001. Each firm's ownership structure is tracked from the year before it lists in the U.S. to five years after the cross-listing. A minimum of three years of ownership data is used as a constraint to include a firm in the sample. $\Delta \mathrm{VR}(-2,-1)$ is the change in mean voting rights of the controlling shareholder in the years prior to cross-listing year(from two years prior to on year prior), $\Delta \mathrm{VR}(-1,0)$ is the change in mean voting rights of the controlling shareholder from year -1 to the year of cross-listing, $\Delta \mathrm{VR}(-1,1)$ is the change in mean voting rights of the controlling shareholder from year -1 to one year after cross-listing, $\Delta \mathrm{VR}(-1,3)$ is the change in mean voting rights of the controlling

shareholder from year -1 to three years after cross-listing and $\Delta \mathrm{VR}(-1,5)$ is the change in mean voting rights of the controlling shareholder from year -1 to five years after crosslisting . Changes in voting rights are also calculated for a comparison sample for the period $\Delta \mathrm{VR}(-1,3)$. For each country in the sample, if the number of firms cross-listing is less than 5 , then for each firm, ownership statistics are reported for a matching firm in the same industry (four-digit SIC) and nearest asset size which does not cross-list. If the number of firms cross-listing is greater than 5, then the comparison sample is generated for a random selection of five cross-listing firms in the country. Results are presented for all firms at the $20 \%$ cut-off level and at the $10 \%$ cut-off level. A mean test is used to test whether the mean change in voting rights is significantly different from zero. Detailed variable definitions and sources are given in the appendix.

Panel A: At the 20\% cut-off level

\begin{tabular}{|c|c|c|c|c|c|c|}
\hline $\begin{array}{l}\text { Year Relative to } \\
\text { Cross-Listing Year }\end{array}$ & Full Sample & Comparison & $\begin{array}{c}\text { English Common } \\
\text { Law }\end{array}$ & French Civil Law & German Civil Law & $\begin{array}{l}\text { Scandinavian and } \\
\text { Socialist Law }\end{array}$ \\
\hline$\Delta \mathrm{VR}(-2,-1)$ & -0.41 & & 0.05 & -0.82 & -0.43 & . \\
\hline$\Delta \mathrm{VR}(-1,0)$ & $-2.63 * * *$ & & $-2.25 * *$ & $-3.63 * * *$ & $-1.01 *$ & -2.36 \\
\hline$\Delta \operatorname{VR}(-1,1)$ & $-3.92 * * *$ & & $-2.42 * *$ & $-5.98 * * *$ & -2.77 & -2.76 \\
\hline$\Delta \operatorname{VR}(-1,3)$ & $-5.76^{* * *}$ & -2.96 & $-2.52 *$ & $-9.38 * * *$ & -4.46 & -1.16 \\
\hline$\Delta \mathrm{VR}(-1,5)$ & $-5.15 * * *$ & & 1.96 & $-9.11 * * *$ & -8.87 & $-2.83^{*}$ \\
\hline
\end{tabular}

$*, * *$ and ${ }^{* * *}$ represent significance at $10 \%, 5 \%$ and $1 \%$ level respectively

Panel B: At the 10\% cut-off level

\begin{tabular}{|c|c|c|c|c|c|c|}
\hline $\begin{array}{l}\text { Year Relative to } \\
\text { Cross-Listing Year }\end{array}$ & Full Sample & Comparison & $\begin{array}{c}\text { English Common } \\
\text { Law } \\
\end{array}$ & French Civil Law & $\begin{array}{c}\text { German Civil } \\
\text { Law } \\
\end{array}$ & $\begin{array}{c}\text { Scandinavian and } \\
\text { Socialist Law }\end{array}$ \\
\hline$\Delta \operatorname{VR}(-2,-1)$ & -0.48 & & 0.13 & -1.01 & -0.45 & . \\
\hline$\Delta \mathrm{VR}(-1,0)$ & $-2.33 * * *$ & & $-1.71 *$ & $-3.41 * * *$ & $-0.81 * *$ & -2.28 \\
\hline$\Delta \operatorname{VR}(-1,1)$ & $-3.65 * * *$ & & $-1.96 * *$ & $-5.72 * * *$ & $-2.72 *$ & -2.75 \\
\hline$\Delta \operatorname{VR}(-1,3)$ & $-6.03 * * *$ & -3.45 & $-3.39 * * *$ & $-9.31 * * *$ & -4.09 & -2.2 \\
\hline$\Delta \mathrm{VR}(-1,5)$ & $-5.46 * * *$ & & 1.08 & $-9.03 * * *$ & $-9.28 *$ & -2.16 \\
\hline
\end{tabular}




\section{Table VI}

\section{Changes in Voting Rights Surrounding Cross-Listing-Comparison by Shareholder Type}

The table shows the changes in voting rights of the original controlling shareholder for the sample of foreign firms that cross-listed on one of the major US exchanges during the years 1990 to 2001. Each firm's ownership structure is tracked from the year before it lists in the U.S. to five years after the cross-listing. A minimum of three years of ownership data is used as a constraint to include a firm in the sample. $\Delta \mathrm{VR}(-2,-1)$ is the change in mean voting rights of the controlling shareholder in the years prior to cross-listing year(from two years prior to on year prior), $\Delta \mathrm{VR}(-1,0)$ is the change in mean voting rights of the controlling shareholder from year -1 to the year of cross-listing, $\Delta \mathrm{VR}(-1,1)$ is the change in mean voting rights of the controlling shareholder from year -1 to one year after cross-listing, $\Delta \mathrm{VR}(-1,3)$ is the change in mean voting rights of the controlling

shareholder from year -1 to three years after cross-listing and $\Delta \mathrm{VR}(-1,5)$ is the change in mean voting rights of the controlling shareholder from year -1 to five years after crosslisting . Changes in voting rights are also calculated for a comparison sample for the period $\Delta \mathrm{VR}(-1,3)$. For each country in the sample, if the number of firms cross-listing is less than 5, then for each firm, ownership statistics are reported for a matching firm in the same industry (four-digit SIC) and nearest asset size which does not cross-list. If the number of firms cross-listing is greater than 5, then the comparison sample is generated for a random selection of five cross-listing firms in the country. Results are presented for all firms at the $20 \%$ cut-off level and at the $10 \%$ cut-off level. A median test is used to test whether the median change in voting rights is significant. Detailed variable definitions and sources are given in the appendix.

Panel A: At the 20\% cut-off level

\begin{tabular}{|c|c|c|c|c|c|c|c|}
\hline $\begin{array}{c}\text { Year Relative to } \\
\text { Cross-Listing Year }\end{array}$ & Full Sample & Comparison & Family & State & $\begin{array}{l}\text { Widely held } \\
\text { Corporation }\end{array}$ & $\begin{array}{l}\text { Widely held } \\
\text { Financial }\end{array}$ & Miscellaneous \\
\hline$\Delta \operatorname{VR}(-2,-1)$ & -0.41 & & 0.03 & -2.55 & 1.66 & 0.85 & -1.13 \\
\hline$\Delta \mathrm{VR}(-1,0)$ & $-2.63^{* * *}$ & & $-2.60^{* *}$ & $-7.67^{* * *}$ & -6.57 & -5.82 & $-2.31^{* *}$ \\
\hline$\Delta \operatorname{VR}(-1,1)$ & $-3.92^{* * *}$ & & $-2.80^{* *}$ & $-11.38^{* * *}$ & $-17.89^{* *}$ & -12.54 & -3.65 \\
\hline$\Delta \operatorname{VR}(-1,3)$ & $-5.76^{* * *}$ & -2.96 & $-5.78^{* * *}$ & $-17.16^{* * *}$ & $-26.74^{* * *}$ & -14.50 & -3.161 \\
\hline$\Delta \mathrm{VR}(-1,5)$ & $-5.15^{* * *}$ & & $-3.89^{*}$ & $-21.99^{* * *}$ & -23.76 & -0.68 & -6.69 \\
\hline
\end{tabular}

$*, * *$ and ${ }^{* * *}$ represent significance at $10 \%, 5 \%$ and $1 \%$ level respectively

Panel B: At the 10\% cut-off level

\begin{tabular}{|c|c|c|c|c|c|c|c|}
\hline $\begin{array}{c}\text { Year Relative to } \\
\text { Cross-Listing Year }\end{array}$ & Full Sample & Comparison & Family & State & $\begin{array}{l}\text { Widely held } \\
\text { Corporation }\end{array}$ & $\begin{array}{l}\text { Widely held } \\
\text { Financial }\end{array}$ & Miscellaneous \\
\hline$\Delta \operatorname{VR}(-2,-1)$ & -0.48 & & 0.003 & $-2.88^{*}$ & 1.37 & 0.62 & -0.85 \\
\hline$\Delta \mathrm{VR}(-1,0)$ & $-2.33^{* * *}$ & & $-1.75^{* *}$ & $-7.06^{* * *}$ & -4.25 & -4.31 & $-1.55^{*}$ \\
\hline$\Delta \operatorname{VR}(-1,1)$ & $-3.65^{* * *}$ & & $-2.01^{* *}$ & $-10.47^{* * *}$ & $-16.12^{* *}$ & -5.31 & -2.74 \\
\hline$\Delta \operatorname{VR}(-1,3)$ & $-6.03^{* * *}$ & -3.45 & $-4.82^{* * *}$ & $-16.21^{* * *}$ & $-21.57^{* *}$ & 7.80 & -2.36 \\
\hline$\Delta \mathrm{VR}(-1,5)$ & $-5.46^{* * *}$ & & $-3.09^{*}$ & $-20.59^{* * *}$ & -17.92 & $-6.27^{*}$ & -4.81 \\
\hline
\end{tabular}

$*, * *$ and $* * *$ represent significance at $10 \%, 5 \%$ and $1 \%$ level respectively 


\section{Table VII}

\section{Controlling Shareholder Dynamics Surrounding Cross-Listing}

The table shows the changes in identity of the controlling shareholder upon cross-listing on a major US exchange during the years 1990 to 2001 . Each firm's ownership structure is tracked from the year before it lists in the U.S. to five years after the cross-listing. The original controlling shareholder could be a family (or individual), the state, a widely held corporation, a widely held financial institution or miscellaneous, which includes business groups, voting trusts and foundations. A change of control is registered in one of the

following cases: when the original controlling shareholder divests his entire stake; when the original controlling shareholder sells his stake such that a new ultimate owner now has maximum percentage of the voting rights; if there is no original controlling shareholder but a controlling shareholder emerges post cross-listing. The new controlling shareholder could again be one of five types: a family (or individual), the state, a widely held corporation, a widely held financial institution or miscellaneous, which includes business groups, voting trusts and foundations. Panel A presents the dynamics in the identity of the controlling shareholder prior to and post cross-listing. Panel B presents the percentage change in each type of controlling shareholder. Foreign is a dummy variable identifying if the controlling shareholder of a firm belongs to a country different from the country of incorporation of the firm. Results are presented for all firms at the $10 \%$ cut-off level. Detailed variable definitions and sources are given in the appendix.

Panel A: Controlling Shareholder Dynamics

\section{Post Cross-Listing}

Total

Number of

Control

Changes

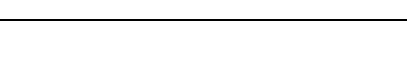

\begin{tabular}{l|l}
\hline & Family \\
& State \\
& Widely-held corporation \\
& Widely-held financial \\
& Miscellaneous \\
& No Controlling \\
& Shareholder \\
& Total \\
\hline
\end{tabular}

\begin{tabular}{c|cccccc} 
Changes & Family & State & corporation & financial & Miscellaneous & \\
\hline 26 & 7 & 1 & 8 & 4 & 3 & 3 \\
22 & 2 & 1 & 9 & 4 & 4 & 2 \\
9 & 2 & 0 & 2 & 3 & 0 & 2 \\
9 & 1 & 0 & 1 & 4 & 0 & 3 \\
7 & 2 & 1 & 0 & 2 & 1 & 0 \\
5 & 2 & 1 & 0 & 1 & 9 & 1 \\
78 & 16 & 4 & 20 & 18 & & \\
\end{tabular}

Panel B: Percentage Changes in Ownership Type from prior to post cross-listing

\begin{tabular}{lc}
\hline $\begin{array}{l}\text { Controlling Shareholder } \\
\text { Type }\end{array}$ & $\begin{array}{c}\text { Percentage } \\
\text { Change }\end{array}$ \\
\hline Family & -11.7 \\
State & -24.2 \\
Corporation & 17.5 \\
Financial & 14.5 \\
Miscellaneous & 3.8 \\
Foreign & 45.3 \\
\hline
\end{tabular}




\section{Table VIII}

Cross Listing versus Domestic Companies: Difference of Medians

The table reports the differences in medians of companies that cross-list and undergo a control change, relative to the control sample, and of companies that cross-list but do not undergo a control change, relative to the control sample. The differences are calculated using quantile median regressions (LAV) where the dependent variable is regressed on a time dummy controlling for calendar year and country effects. The time dummies used are: PRELISTING is a dummy variable that takes value 1 for observations taken 1 year before the company cross lists, CLYEAR is a dummy capturing the timing of the cross-listing ( 1 in the year of cross-listing and 0 elsewhere) and POSTLISTING is a dummy taking the value 1 in the fifth year after cross listing. Each cell in the table below represents a separate LAV regression and presents the coefficients of the time dummies, which is the difference in medians. TOTAL ASSETS is the Total Assets of the firm, LEVERAGE is the leverage ratio of the firm, Q is Tobin's Q ratio given by (market value of assets divided by replacement cost), TASTGR is total asset growth, FINCGR is growth in foreign income, ROA is return on assets. Detailed variable definitions and sources are given in the appendix.

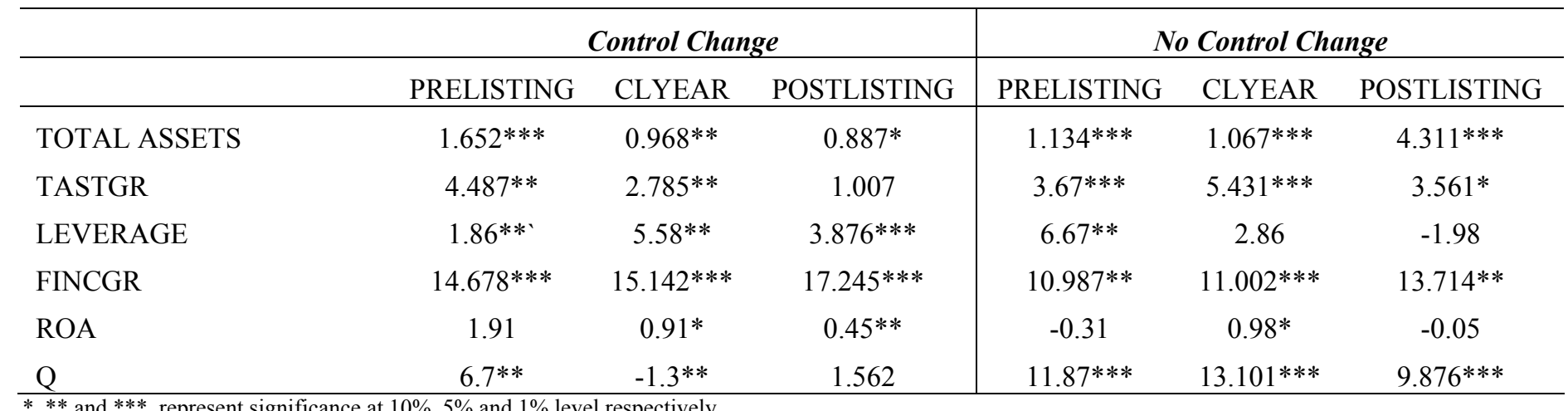




\section{Table IX \\ Predicting Control Change in Cross-Listing Firms}

The table presents the Cox estimates of the hazard ratio of a control change occurring within five years of foreign firms cross-listing on a major US exchange. The dependent variable takes the value one in the year of the first control change and zero otherwise. A change of control is registered in one of the following cases: when the original controlling shareholder divests his entire stake; when the original controlling shareholder sells his stake such that a new ultimate owner now has maximum percentage of the voting rights; if there is no original controlling shareholder but a controlling shareholder emerges post cross-listing. The independent variables are as follows: AGE is the age of the firm from its year of incorporation to the year of cross-listing, SIZE is log of firm's sales, LEVERAGE is the leverage ratio of the firm, Q is Tobin's Q ratio given by (market value of assets divided by replacement cost), TASTGR is total asset growth, FINCGR is growth in foreign income, GDPCAP is log of GDP per capita, TVT is total value traded as a percentage of GDP, COMMON is the legal origin dummy which takes the value 1 for common law countries and 0 otherwise, PROPERTY is the Property Rights Regulation Index from The Index of Economic Freedom.

CAPCONTROL is index of capital controls from the IMF's Trade and Exchange Restrictions Report. Lag values of all independent variables are used. Standard errors and resulting p-values are adjusted for clustering on companies.

Detailed variable definitions and sources are given in the appendix

\begin{tabular}{|c|c|c|c|c|}
\hline No. of subjects & 1284 & & & \\
\hline No. of failures & 78 & & & \\
\hline Log Likelihood : & -262.36 & & & \\
\hline Wald $\chi^{2}(11)$ & $: 47.56$ & & & \\
\hline Prob $>\chi^{2}(11)$ & $: 0.000$ & & & \\
\hline & & Hazard Ratio & $\mathrm{Z}$ & $\mathrm{P}>\mathrm{Z}$ \\
\hline AGE & & 0.955 & -1.43 & 0.125 \\
\hline SIZE & & 1.195 & 3.56 & 0.000 \\
\hline LEVERAGE & & 0.168 & -1.98 & 0.058 \\
\hline Q & & 0.986 & -2.45 & 0.000 \\
\hline TASTGR & & 1.035 & 1.35 & 0.146 \\
\hline FINCGR & & 1.067 & 6.35 & 0.000 \\
\hline GDPCAP & & 1.216 & 2.47 & 0.011 \\
\hline TVT_GDP & & 16.567 & 4.65 & 0.000 \\
\hline COMMON & & 0.183 & -2.03 & 0.041 \\
\hline PROPERTY & & 0.045 & -1.44 & 0.000 \\
\hline CAPCONTROL & & 0.912 & -2.19 & 0.087 \\
\hline
\end{tabular}




\section{Table X}

\section{Predicting the Emergence of Foreign Controlling Owners on Cross-Listing}

The table shows results from a multinomial logit regression that predicts the probability of a control change taking place to a new controlling shareholder who is foreign. The dependent variable is a dummy variable that takes one of four values: 1 (for no control change), 2 (when there is a control change to a new domestic controlling owner), 3 (when there is a control change to a foreign controlling owner) and 4 (when the firm becomes widely held after cross-listing). Group 1 (no control change) is the comparison group. The explanatory variables used are described as follows: Q is Tobin's Q ratio given by (market value of assets divided by replacement cost), SIZE is log of firm's sales, LEVERAGE is the leverage ratio of the firm, AGE is the age of the firm from its year of incorporation to the year of cross-listing, TASTGR is total asset growth, FINCGR is growth in foreign income, GDPCAP is log of GDP per capita, TVT_GDP is total value traded as a percentage of GDP, FDI is the level of foreign direct investment taken from IMF's Balance of Payments Statistics, PROPERTY is Property Rights Regulation Index, YEARS_LIBER is the number of years since the official date of liberalization of the country (from Bekaert and Harvey 1999). Lag values of all independent variables are used. The coefficients reported are the relative risk ratios. Significance levels of the Z-statistics are also reported. Standard errors and resulting p-values are adjusted for clustering on companies. Detailed variable definitions and sources are given in the appendix.

Number of observations: 1987

Log Likelihood: -135.17

Wald $\chi^{2}(38): 194.60$

Prob $>\chi^{2}: 0.00$

Pseudo $\mathrm{R}^{2}: 0.42$

\begin{tabular}{llll}
\hline & \multicolumn{3}{c}{ Relative Risk Ratios } \\
\cline { 2 - 4 } & $\begin{array}{c}\text { Change to a new } \\
\text { controlling owner } \\
\text { (domestic) }\end{array}$ & $\begin{array}{c}\text { Change to a new } \\
\text { controlling owner } \\
\text { (foreign) }\end{array}$ & $\begin{array}{c}\text { Change to widely } \\
\text { held }\end{array}$ \\
\hline Q & 0.999 & 0.999 & $1.002^{*}$ \\
SIZE & $1.046^{*}$ & $0.588^{* *}$ & $0.025^{* *}$ \\
LEVERAGE & 0.873 & $0.295^{* * *}$ & 1.022 \\
AGE & 0.992 & 0.982 & $0.295^{* *}$ \\
TASTGR & 0.998 & 0.999 & 0.984 \\
FINCGR & 1.003 & $1.151^{* *}$ & 1.002 \\
GDPCAP & $3.321^{* * *}$ & 2.518 & 1.381 \\
TVT_GDP & $13.685^{* *}$ & $0.003^{* * *}$ & 0.013 \\
PROPERTY & $0.726^{* * *}$ & 1.101 & $1.587^{* * *}$ \\
FDI & 1.121 & $1.828^{* * *}$ & 1.231 \\
YEARS_LIBER & $0.903^{*}$ & 0.884 & 0.948 \\
\hline$* * * * a * *$
\end{tabular}

${ }^{*}, * *$ and ${ }^{* * *}$ represent significance at $10 \%, 5 \%$ and $1 \%$ level respectively 


\section{Table XI \\ Effect of FDI Restrictions on Control Change in OECD Countries}

The table shows results from a multinomial logit regression that predicts the effect of restrictions on foreign direct investment on control change in OECD countries. The dependent variable is a dummy variable that takes one of four values: 1 (for no control change), 2 (when there is a control change to a new domestic controlling owner), 3 (when there is a control change to a foreign controlling owner) and 4 (when the firm becomes widely held after cross-listing). Group 1 (no control change) is the comparison group. The explanatory variables used are described as follows: Q is Tobin's Q ratio given by (market value of assets divided by replacement cost), SIZE is log of firm's sales, LEVERAGE is the leverage ratio of the firm, AGE is the age of the firm from its year of incorporation to the year of cross-listing, TASTGR is total asset growth, FINCGR is growth in foreign income, GDPCAP is log of GDP per capita, TVT_GDP is total value traded as a percentage of GDP, FDI is the level of foreign direct investment taken from IMF's Balance of Payments Statistics, YEARS_LIBER is the number of years since the official date of liberalization of the country (from Bekaert and Harvey 1999), RESTRICTION is a composite OECD measure of restrictions on foreign direct investment which includes restrictions on foreign equity ownership (from Golub 2003). Lag values of all independent variables are used. The coefficients reported are the relative risk ratios. Significance levels of the Z-statistics are reported. Standard errors and resulting p-values are adjusted for clustering on companies. Detailed variable definitions and sources are given in the appendix.

Number of observations:

Log Likelihood: -67.349

Wald $\chi^{2}$ (20): 75.39

Prob $>\chi^{2}: 0.00$

Pseudo $R^{2}: 0.36$

\begin{tabular}{llc}
\hline & \multicolumn{2}{c}{ Relative Risk Ratios } \\
\cline { 2 - 3 } & \multicolumn{1}{c}{$\begin{array}{c}\text { Change to a new } \\
\text { controlling owner } \\
\text { (domestic) }\end{array}$} & $\begin{array}{c}\text { Change to a new } \\
\text { controlling owner } \\
\text { (foreign) }\end{array}$ \\
\hline Q & $0.999^{* *}$ & 0.999 \\
SIZE & $1.389^{* * *}$ & 0.531 \\
LEVERAGE & 0.876 & 0.583 \\
AGE & 1.009 & 0.966 \\
TASTGR & 0.978 & 0.998 \\
FINCGR & 1.001 & $1.063^{*}$ \\
GDPCAP & $2.629^{* * *}$ & 1.09 \\
TVT_GDP & $18.409^{* * *}$ & 1.335 \\
PROPERTY & $0.586^{* * *}$ & 0.726 \\
FDI & $1.625^{*}$ & $1.873^{* *}$ \\
YEARS_LIBER & $0.459^{* * *}$ & 0.705 \\
RESTRICTION & 5.303 & $0.061 * *$ \\
\hline$* * *$ and *** represent significance at $10 \%, 5 \%$ and $1 \%$ level respectively
\end{tabular}




\section{Table XII}

Ex-Post Regressions Distinguishing between Firms with and without Control Changes

The table shows the estimates of the ex-post effects of cross-listing distinguishing between firms that underwent a control change and those that did not experience a control change. Panel A presents results for companies that did not have any control changes and Panel B presents results for companies that underwent a control change. Each column gives the results of a LAV regression for a dependent variable. The explanatory variables are CLYEAR which is a dummy capturing the timing of the cross-listing (1 in the year of cross-listing and 0 elsewhere), YEAR3 which is a dummy taking the value 1 in the three years after cross-listing and YEAR5 which is a dummy taking the value 1 after the third year). A constant, country on incorporation and calendar year dummies are also included but the coefficients are not reported here. First differences of all variables are taken to eliminate fixed effects. Detailed variable definitions and sources are given in the appendix.

\section{Panel A: No Control Change}

\begin{tabular}{|c|c|c|c|c|c|c|}
\hline & 1 & 2 & 3 & 4 & 5 & 6 \\
\hline & Total Assets & $\begin{array}{l}\text { Total Assets } \\
\text { Growth }\end{array}$ & $\begin{array}{l}\text { Foreign Income } \\
\text { Growth }\end{array}$ & Leverage & Return on Assets & Tobin's $Q$ \\
\hline Year of Cross-Listing & 0.045 & $6.790 * * *$ & $0.225 * *$ & $-0.090 * * *$ & 0.53 & 0.987 \\
\hline Three-year effect & -0.016 & 0.06 & $0.312 * *$ & 0.002 & $-0.33 * * *$ & $1.023^{*}$ \\
\hline Five-year effect & 0.014 & -2.35 & $0.556 * *$ & -0.025 & -0.12 & $2.194 * *$ \\
\hline Pseudo R-squared & 0.00 & 0.02 & 0.00 & 0.05 & 0.00 & 0.00 \\
\hline $\mathbf{N}$ & 1567 & 1470 & 1362 & 1293 & 1436 & 1171 \\
\hline
\end{tabular}

Panel B: Control Change

\begin{tabular}{|c|c|c|c|c|c|c|}
\hline & 1 & 2 & 3 & 4 & 5 & 6 \\
\hline & Total Assets & $\begin{array}{c}\text { Total Assets } \\
\text { Growth }\end{array}$ & $\begin{array}{c}\text { Foreign Income } \\
\text { Growth }\end{array}$ & Leverage & Return on Assets & Tobin's $Q$ \\
\hline Year of Cross-Listing & 0.035 & $7.880 * * *$ & $2.178 * *$ & -0.086 & 0.42 & 0.235 \\
\hline Three-year effect & 0.057 & 0.16 & $1.222 * *$ & $1.003 *$ & 1.07 & -1.246 \\
\hline Five-year effect & $-0.236 * *$ & 1.14 & $2.289 * * *$ & $2.669 * * *$ & $0.580^{*}$ & $-1.632 * * *$ \\
\hline Pseudo R-squared & 0.01 & 0.00 & 0.00 & 0.04 & 0.01 & 0.00 \\
\hline 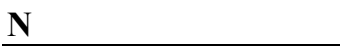 & 412 & 351 & 368 & 406 & 365 & 325 \\
\hline
\end{tabular}

\begin{tabular}{|c|c|c|c|c|c|c|}
\hline & 1 & 2 & 3 & 4 & 5 & 6 \\
\hline & Total Assets & $\begin{array}{c}\text { Total Assets } \\
\text { Growth }\end{array}$ & $\begin{array}{c}\text { Foreign Income } \\
\text { Growth }\end{array}$ & Leverage & Return on Assets & Tobin's $Q$ \\
\hline Year of Cross-Listing & 0.035 & $7.880 * * *$ & $2.178 * *$ & -0.086 & 0.42 & 0.235 \\
\hline Three-year effect & 0.057 & 0.16 & $1.222 * *$ & $1.003^{*}$ & 1.07 & -1.246 \\
\hline Five-year effect & $-0.236^{* *}$ & 1.14 & $2.289 * * *$ & $2.669 * * *$ & $0.580^{*}$ & $-1.632 * * *$ \\
\hline Pseudo R-squared & 0.01 & 0.00 & 0.00 & 0.04 & 0.01 & 0.00 \\
\hline $\mathbf{N}$ & 412 & 351 & 368 & 406 & 365 & 325 \\
\hline
\end{tabular}

\begin{tabular}{|c|c|c|c|c|c|c|}
\hline & 1 & 2 & 3 & 4 & 5 & 6 \\
\hline & Total Assets & $\begin{array}{c}\text { Total Assets } \\
\text { Growth }\end{array}$ & $\begin{array}{c}\text { Foreign Income } \\
\text { Growth }\end{array}$ & Leverage & Return on Assets & Tobin's $Q$ \\
\hline Year of Cross-Listing & 0.035 & $7.880 * * *$ & $2.178 * *$ & -0.086 & 0.42 & 0.235 \\
\hline Three-year effect & 0.057 & 0.16 & $1.222 * *$ & $1.003 *$ & 1.07 & -1.246 \\
\hline Five-year effect & $-0.236 * *$ & 1.14 & $2.289 * * *$ & $2.669 * * *$ & $0.580^{*}$ & $-1.632 * * *$ \\
\hline Pseudo R-squared & 0.01 & 0.00 & 0.00 & 0.04 & 0.01 & 0.00 \\
\hline $\mathbf{N}$ & 412 & 351 & 368 & 406 & 365 & 325 \\
\hline
\end{tabular}

$\frac{\mathbf{N}}{*, * *}$ and ${ }^{* * *}$ represent significance at $10 \%, 5 \%$ and $1 \%$ level respectively 
Appendix A

Variable Definitions

\section{Variable}

\section{Ownership Variables}

Widely held

Family

State

Widely-held corporation

Widely-held financial

Miscellaneous

Cross-Shs

Pyramid

Single

Management

\section{Firm-level Variables}

AGE

SIZE

LEVERAGE

TASTGR

FINCR

$\mathrm{Q}$

ROA

\section{Definition}

Equals 1 if there is no controlling shareholder. Control is measured following LLSV (???)

Equals 1 if a person or family is controlling shareholder, and zero otherwise

Equals 1 if domestic or foreign state is controlling shareholder, and zero otherwise

Equals 1 if a widely held non-financial company is controlling shareholder, and zero otherwise

Equals 1 if a widely held financial company is controlling shareholder, and zero otherwise

Equals 1 if above five categories are zero. Includes pension funds, voting trusts, groups, non-profit organizations and employees

Equals 1 if firm has a controlling shareholder and owns shares in its controlling shareholder or in firm that belongs to the chain of control, zero otherwise

Equals 1 if controlling shareholder exercises control through at least one publicly traded company, and zero otherwise

Equals 1 if firm has a $20 \%$ (or 10\%) controlling shareholder and no other shareholder has control of at least 10 percent of the votes

Equals 1 if controlling shareholder is also CEO, Chairman, Vice-Chairman of the Board, and zero otherwise

Time since the date of incorporation of the company

Log of Sales. Source: Worldscope

Total Assets/ Shareholder's Equity. Source: Worldscope

Total Asset Growth. Source: Worldscope

Foreign Income Growth. Source: Worldscope

Tobins Q Ratio ((Market Value of Equity+Long Term Debt)/Replacement Value(Net property, plant \&

equipment+Inventory). Source: Worldscope

Return on Assets. Source: Worldscope 


\begin{tabular}{|c|c|}
\hline Variable & Definition \\
\hline \multicolumn{2}{|l|}{ Country-level Variables } \\
\hline GDPGROWTH & Growth in GDP per capita. Source: World Development Indicators \\
\hline TVT_GDP & Total Value of Stocks Traded as a percentage of GDP. Source: World Bank Financial Structure Database \\
\hline FDI & Foreign Direct Investment. Source: IMF Balance of Payments Statistics \\
\hline YEARS_LIBER & Time elapsed since the official liberalization date of the country. The official liberalization dates are reported in \\
\hline PROPERTY & The degree to which property rights are protected in the economy. Source: Heritage Foundation \\
\hline RESTRICTION & $\begin{array}{l}\text { OECD Measure of FDI restriction for each country. The total score ranges from } 0 \text { to } 1 \text { and is based on regulations in } \\
\text { each of three areas: (1) Restrictions on foreign ownership (2) Obligatory screening and approval procedures used to } \\
\text { limit FDI (3) Other formal restrictions including constraints on the ability of foreign nationals to manage or work in } \\
\text { affiliates of foreign companies and other operational controls on these businesses. Source: Golub (2003) }\end{array}$ \\
\hline CAPITAL CONTROLS & Index of Capital Controls. Source: IMF Trade and Exchange Restrictions Report;Harrison, Love and McMillan(2002) \\
\hline ACCOUNTING & $\begin{array}{l}\text { Index created by examining and rating companies' } 1990 \text { annual reports on their inclusion or omission of } 90 \text { items in } \\
\text { balance sheets and income statements and published by the Center for International Financial Analysis \& Research Inc. } \\
\text { the maximum is } 90 \text {, the minimum is } 0 .\end{array}$ \\
\hline RULE OF LAW & $\begin{array}{l}\text { Measure of the law and order tradition of a country. Ranges from 1(weak) to 10(strong). Source: International Country } \\
\text { Risk Guide }\end{array}$ \\
\hline JUDICIAL EFFICIENCY & $\begin{array}{l}\text { Assessment of the efficiency and integrity of the legal environment as it affects business. Scale from 0-10. Source: } \\
L L S V 1999\end{array}$ \\
\hline OVERALL SIZE & $\begin{array}{l}\text { Overall size of the financial system (Deposit money bank assets and stock market capitalization as share of GDP). } \\
\text { Source: World Bank Financial Structure Database }\end{array}$ \\
\hline MARKET & Index of Financial Structure. Higher values indicate a more market based system. Source: Beck et. al(2000) \\
\hline DEVELOPED & $\begin{array}{l}\text { Equals zero if both priv(claims on private sector by deposit money banks as a share of GDP) and tvt_gdp are below the } \\
\text { period mean }\end{array}$ \\
\hline
\end{tabular}




\section{Appendix B}

\section{Sources of Ownership Data}

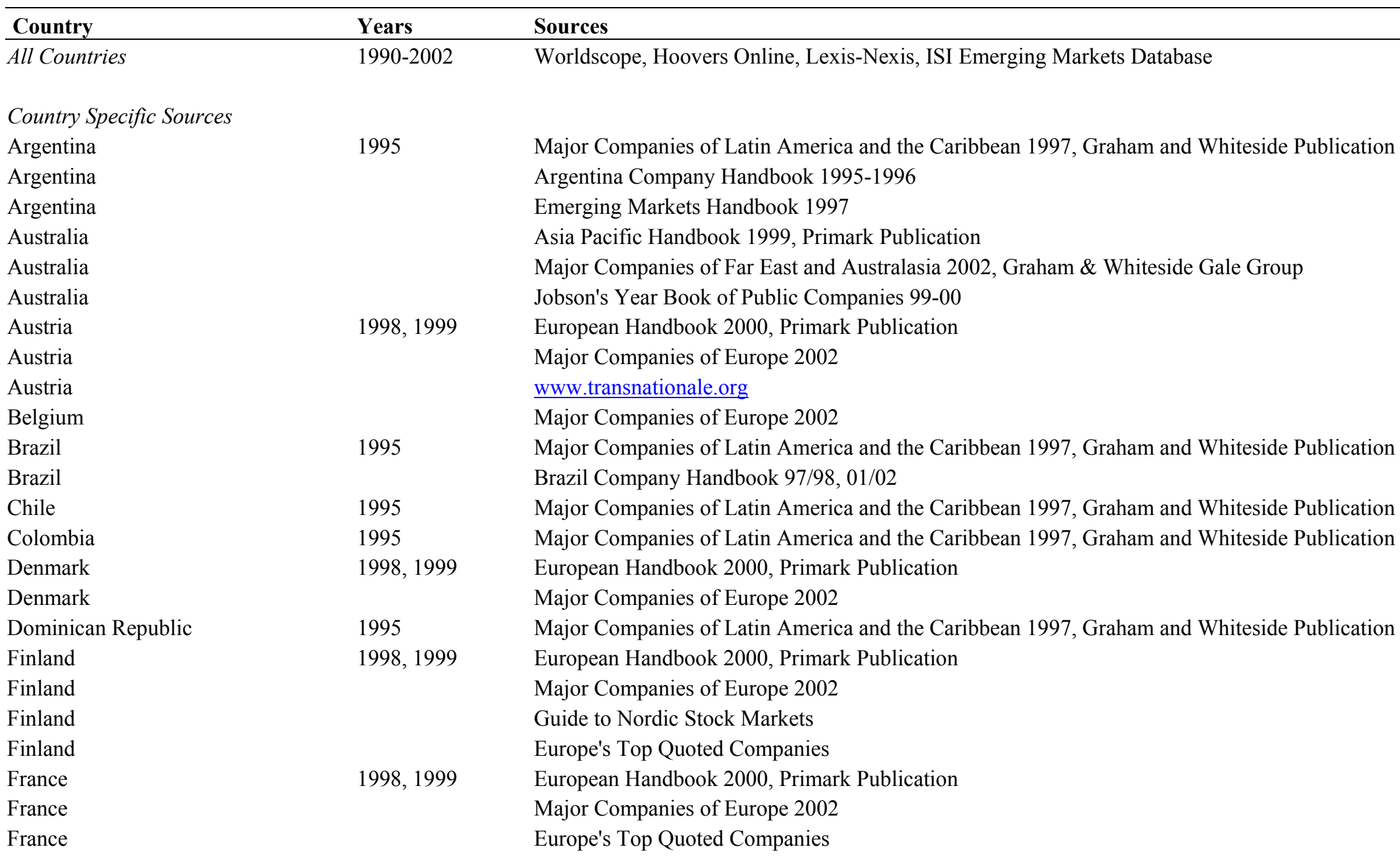




\begin{tabular}{|c|c|c|}
\hline Country & Years & Sources \\
\hline Germany & 1998, 1999 & European Handbook 2000, Primark Publication \\
\hline Germany & & Major Companies of Europe 2002 \\
\hline Germany & & Europe's Top Quoted Companies \\
\hline Greece & & Major Companies of Europe 2002 \\
\hline Greece & & Europe's Top Quoted Companies \\
\hline Hong Kong & 1996, 1997 & Asian Company Handbook 1999, Toyo Keizai Publication \\
\hline Hong Kong & & Asia Pacific Handbook 1999, Primark Publication \\
\hline Hong Kong & & Major Companies of Far East and Australasia 2002, Graham \& Whiteside Gale Group \\
\hline India & 1996,1997 & Asian Company Handbook 1999, Toyo Keizai Publication \\
\hline \multicolumn{3}{|l|}{ India } \\
\hline Indonesia & 1996,1997 & Asian Company Handbook 1999, Toyo Keizai Publication \\
\hline Indonesia & & Major Companies of Far East and Australasia 2002, Graham \& Whiteside Gale Group \\
\hline Indonesia & & Emerging Markets Handbook 1997 \\
\hline Ireland & & Europe's Top Quoted Companies \\
\hline Israel & & Major Companies of Europe 2002 \\
\hline Italy & & Europe's Top Quoted Companies \\
\hline Italy & & Major Companies of Europe 2002 \\
\hline Japan & & Asia Pacific Handbook 1999, Primark Publication \\
\hline Japan & & Morningstar Japan, July 1992, 1994 \\
\hline Japan & & Major Companies of Far East and Australasia 2002, Graham \& Whiteside Gale Group \\
\hline Luxembourg & & Major Companies of Europe 2002 \\
\hline Malaysia & & Asia Pacific Handbook 1999, Primark Publication \\
\hline Malaysia & & Kuala Lumpur Stock Exchange Annual Companies Handbook 1996 \\
\hline Mexico & 1995 & Major Companies of Latin America and the Caribbean 1997, Graham and Whiteside Publication \\
\hline Mexico & & Mexico Company Handbook 1995-96 \\
\hline Netherlands & & Europe's Top Quoted Companies \\
\hline Netherlands & & Dutch Company Handbook 1998-99 \\
\hline New Zealand & & Major Companies of Far East and Australasia 2002, Graham \& Whiteside Gale Group \\
\hline New Zealand & & Jobson's Year Book of Public Companies 99-00 \\
\hline Norway & 1998,1999 & European Handbook 2000, Primark Publication \\
\hline
\end{tabular}




\begin{tabular}{|c|c|c|}
\hline Country & Years & Sources \\
\hline Norway & & Europe's Top Quoted Companies \\
\hline Norway & & Guide to Nordic Stock Markets \\
\hline Peru & 1995 & Major Companies of Latin America and the Caribbean 1997, Graham and Whiteside Publication \\
\hline Philippines & 1996,1997 & Asian Company Handbook 1999, Toyo Keizai Publication \\
\hline Philippines & & Major Companies of Far East and Australasia 2002, Graham \& Whiteside Gale Group \\
\hline Portugal & & Major Companies of Europe 2002 \\
\hline Portugal & & Portuguese Stock Exchange 1993 \\
\hline Portugal & & Europe's Top Quoted Companies \\
\hline Portugal & & Emerging Markets Handbook 1997 \\
\hline Russia & & Russian Equity Guide 96-97, Brunswick Brokerage' \\
\hline Russia & & Russian Equity Guide 2000-01 \\
\hline Singapore & 1996, 1997 & Asian Company Handbook 1999, Toyo Keizai Publication \\
\hline Singapore & & Asia Pacific Handbook 1999, Primark Publication \\
\hline Singapore & & Major Companies of Far East and Australasia 2002, Graham \& Whiteside Gale Group \\
\hline South Africa & $1996,1997,1998$ & McGregors's Who Owns Whom in South Africa, 1998 Listed and Unlisted Companies, McGregor Publication \\
\hline South Africa & $1994,1995,1996$ & McGregors's Who Owns Whom in South Africa, 1996 Listed and Unlisted Companies, McGregor Publication \\
\hline South Korea & 1996, 1997 & Asian Company Handbook 1999, Toyo Keizai Publication \\
\hline South Korea & & Major Companies of Far East and Australasia 2002, Graham \& Whiteside Gale Group \\
\hline South Korea & & Korea Company Handbook Investment Guide, Daewoo Securities Co., Ltd. \\
\hline South Korea & & Emerging Markets Handbook 1997 \\
\hline South Korea & & Korea Company Handbook 2000 \\
\hline South Korea & & Asia Pacific Handbook 1999, Primark Publication \\
\hline Spain & 1998,1999 & European Handbook 2000, Primark Publication \\
\hline Spain & & Major Companies of Europe 2002 \\
\hline Spain & & Europe's Top Quoted Companies \\
\hline Sweden & 1998,1999 & European Handbook 2000, Primark Publication \\
\hline Sweden & & Europe's Top Quoted Companies \\
\hline Sweden & & Major Companies of Europe 2002 \\
\hline Switzerland & 1998,1999 & European Handbook 2000, Primark Publication \\
\hline Switzerland & & Major Companies of Europe 2002 \\
\hline
\end{tabular}




\begin{tabular}{lll}
\hline Country & Years & Sources \\
\hline Switzerland & & Europe's Top Quoted Companies \\
Taiwan & 1996,1997 & Asian Company Handbook 1999, Toyo Keizai Publication \\
Taiwan & & Major Companies of Far East and Australasia 2002, Graham \& Whiteside Gale Group \\
Taiwan & & Emerging Markets Handbook 1997 \\
Thailand & & Asia Pacific Handbook 1999, Primark Publication \\
Thailand & \\
UK & & \\
UK & 1998,1999 & European Handbook 2000, Primark Publication \\
UK & & Europe's Top Quoted Companies \\
Venezuela & Major Companies of Europe 2002 \\
\hline
\end{tabular}




\section{Appendix C \\ Country Characteristics}

GDP per capita is the real GDP per capita averaged over the period 1990-1999. TVT GDP is Total Value of Stocks Traded as a percentage of GDP averaged over 1990-99. COMMON is a dummy variable which takes the value 1 for English common law countries and 0 for others. PROPERTY is the Property Rights Regulation Index from The Index of Economic Freedom. CAPCONTROL is index of capital controls from the IMF's Trade and Exchange Restrictions Report, averaged over 1990-96. FDI is the level of foreign direct investment taken from IMF's Balance of Payments Statistics, averaged over 1990-99. RESTRICTION is a composite OECD measure of restrictions on foreign direct investment which includes restrictions on foreign equity ownership (from Golub 2003).

\begin{tabular}{|c|c|c|c|c|c|c|c|}
\hline Nation & $\begin{array}{l}\text { GDP/CAP } \\
\text { (US \$) } \\
\end{array}$ & TVT_GDP & COMMON & PROPERTY & $\begin{array}{l}\text { CAPITAL } \\
\text { CONTROL } \\
\end{array}$ & LEVEL OF FDI & $\begin{array}{l}\text { (OECD) FDI } \\
\text { RESTRICTION }\end{array}$ \\
\hline Argentina & 7440.86 & 0.04 & 0 & 4 & 3.00 & 2.59 & . \\
\hline Australia & 20498.74 & 0.29 & 1 & 5 & 0.08 & 1.82 & 0.33 \\
\hline Austria & 29344.73 & 0.07 & 0 & 5 & 0.55 & 1.07 & 0.43 \\
\hline Belgium & 27304.92 & 0.09 & 0 & 5 & 0.40 & 2.20 & 0.29 \\
\hline Brazil & 4298.29 & 0.13 & 0 & 3 & 2.43 & 1.58 & . \\
\hline Colombia & 2289.70 & 0.01 & 0 & 3 & 3.89 & 2.14 & . \\
\hline Denmark & 34167.82 & 0.20 & 0 & 5 & 0.40 & 2.47 & 0.16 \\
\hline Dominican Republic & 1588.07 & $\cdot$ & 0 & 2 & . & 2.89 & . \\
\hline Finland & 26289.28 & 0.23 & 0 & 5 & 0.50 & 1.96 & 0.46 \\
\hline France & 26986.50 & 0.23 & 0 & 4 & 1.40 & 1.66 & 0.23 \\
\hline Germany & 30004.38 & 0.27 & 0 & 5 & 0.08 & 0.58 & 0.17 \\
\hline Greece & 11455.06 & 0.24 & 0 & 4 & . & 0.96 & 0.33 \\
\hline Hong Kong, China & 21994.46 & 1.15 & 1 & 5 & 0.00 & & . \\
\hline Hungary & 4526.60 & 0.10 & 0 & 4 & $\cdot$ & 4.65 & . \\
\hline India & 375.75 & 0.08 & 1 & 3 & 3.50 & 0.39 & . \\
\hline Indonesia & 966.93 & 0.09 & 0 & 3 & 1.00 & 1.06 & . \\
\hline Ireland & 18767.87 & 0.28 & 1 & 5 & 1.30 & 5.22 & 0.25 \\
\hline
\end{tabular}




\begin{tabular}{|c|c|c|c|c|c|c|c|}
\hline Nation & $\begin{array}{l}\text { GDP/CAP } \\
\text { (US \$) }\end{array}$ & TVT_GDP & COMMON & PROPERTY & $\begin{array}{l}\text { CAPITAL } \\
\text { CONTROL }\end{array}$ & LEVEL OF FDI & $\begin{array}{l}\text { (OECD) FDI } \\
\text { RESTRICTION }\end{array}$ \\
\hline Israel & 15343.58 & 0.18 & 1 & 4 & 2.00 & 1.24 & . \\
\hline Italy & 19050.73 & 0.14 & 0 & 4 & 1.40 & 0.35 & 0.26 \\
\hline Japan & 42285.18 & 0.29 & 0 & 5 & 0.09 & 0.06 & 0.24 \\
\hline Korea, Rep. & 10261.01 & 0.58 & 0 & 5 & 1.89 & 0.67 & . \\
\hline Luxembourg & 44015.98 & 0.03 & 0 & 5 & . & & . \\
\hline Netherlands & 27063.04 & 0.58 & 0 & 5 & 0.00 & 4.12 & 0.24 \\
\hline New Zealand & 16165.58 & 0.13 & 1 & 5 & 0.00 & 4.05 & 0.24 \\
\hline Norway & 33227.32 & 0.18 & 0 & 5 & 1.50 & 1.74 & 0.47 \\
\hline Peru & 2121.17 & 0.04 & 0 & 3 & 2.43 & 3.07 & . \\
\hline Philippines & 1090.42 & 0.16 & 0 & 4 & 3.00 & 1.72 & . \\
\hline Poland & 2880.74 & 0.04 & 0 & 4 & . & 2.39 & . \\
\hline Russian Federation & 2630.33 & 0.02 & 0 & 3 & . & 0.53 & . \\
\hline Singapore & 22510.88 & 0.75 & 1 & 5 & 0.00 & 10.44 & . \\
\hline South Africa & 3921.59 & 0.21 & 1 & 3 & 4.00 & 0.96 & . \\
\hline Spain & 15025.36 & 0.42 & 0 & 4 & 1.54 & 1.89 & 0.23 \\
\hline Sweden & 27400.20 & 0.44 & 0 & 4 & 0.70 & 5.35 & 0.34 \\
\hline Switzerland & 44520.43 & 1.22 & 0 & 5 & . & 2.04 & 0.28 \\
\hline Taiwan, China & 12141.17 & 2.62 & 0 & . & . & & . \\
\hline Turkey & 2782.34 & 0.21 & 0 & 4 & 3.63 & 0.46 & 0.39 \\
\hline United Kingdom & 19360.10 & 0.60 & 1 & 5 & 0.00 & 2.77 & 0.17 \\
\hline Venezuela & 3519.88 & 0.03 & 0 & 3 & 2.44 & 2.60 & . \\
\hline
\end{tabular}


Appendix D

Example of change in ownership structure

VIMPEL COMMUNICATIONS

Date of incorporation: 1992

ADR Listing: 11/01/1996

Listed on NYSE as Level III ADR

Depositary: Bank of New York

Ownership Structure prior to ADR Listing (Dec 1995) i.e. at t-1

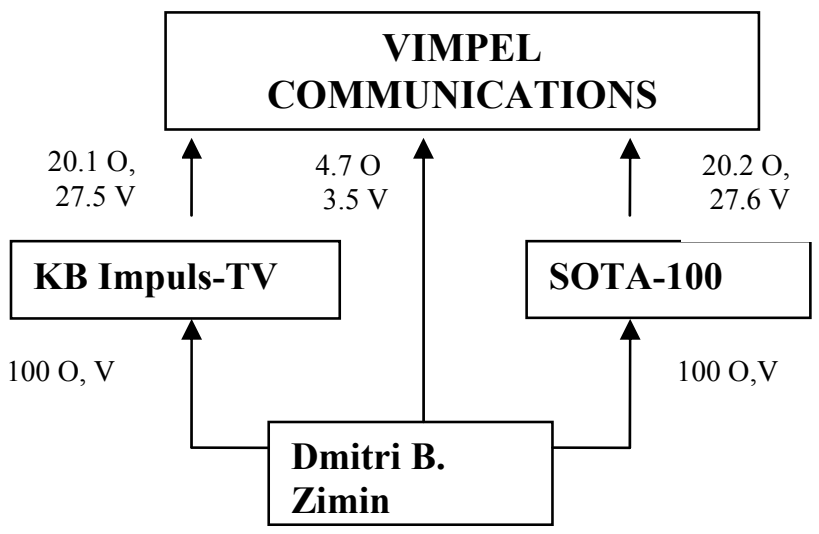

Ownership Structure post ADR Listing (Dec 2001) i.e. at $t+5$

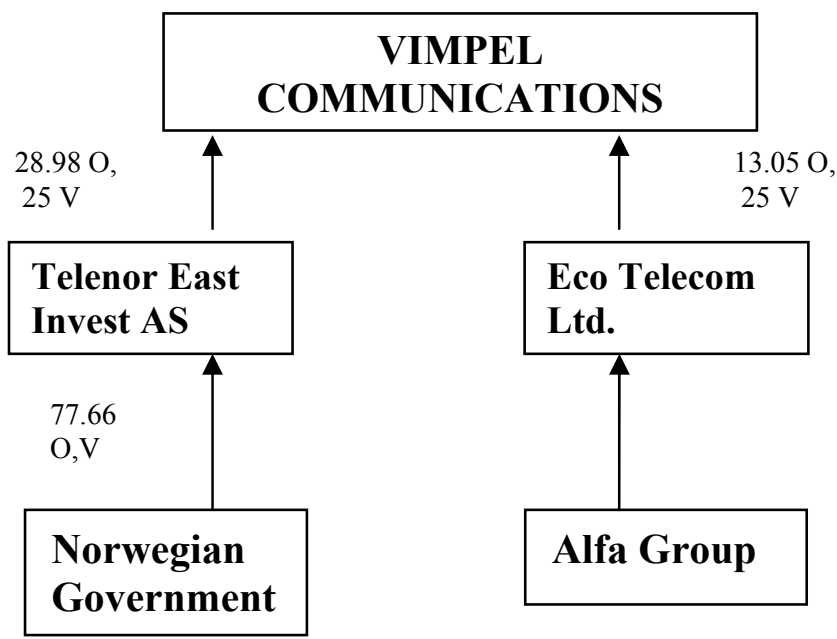

